\title{
Piriformospora indica reduces Fusarium head blight disease severity and mycotoxin DON contamination in wheat under UK weather conditions
}

Article

Accepted Version

Rabiey, M. and Shaw, M. W. (2016) Piriformospora indica reduces Fusarium head blight disease severity and mycotoxin DON contamination in wheat under UK weather conditions. Plant Pathology, 65 (6). pp. 940-952. ISSN 0032-0862 doi: https://doi.org/10.1111/ppa.12483 Available at https://centaur.reading.ac.uk/48683/

It is advisable to refer to the publisher's version if you intend to cite from the work. See Guidance on citing.

To link to this article DOI: http://dx.doi.org/10.1111/ppa.12483

Publisher: Wiley

All outputs in CentAUR are protected by Intellectual Property Rights law, including copyright law. Copyright and IPR is retained by the creators or other copyright holders. Terms and conditions for use of this material are defined in the End User Agreement. 


\section{CentAUR}

Central Archive at the University of Reading

Reading's research outputs online 
1 Short title: Piriformospora indica reduces Fusarium

2 Piriformospora indica reduces Fusarium head blight disease severity and mycotoxin DON 3 contamination in wheat under UK weather conditions

$5 \quad$ M. Rabiey*

6 M. W. Shaw

7 School of Agriculture, Policy and Development, University of Reading, Whiteknights,

$8 \quad$ Reading RG6 6AR

9

10 *Email: m.rabieyghahfarokhy@pgr.reading.ac.uk

15 Key words: Piriformospora indica, root endophytic fungus, Fusarium head blight, Fusarium 16 crown rot, Triticum aestivum, mycotoxin DON 
Summary

Piriformospora indica (Sebacinaceae) is a cultivable root endophytic fungus. It colonises the roots of a wide range of host plants. In many settings colonisation promotes host growth, increases yield and protects the host from fungal diseases. We evaluated the effect of $P$. indica on Fusarium head blight (FHB) disease of winter (cv. Battalion) and spring (cv. Paragon, Mulika, Zircon, Granary, KWS Willow and KWS Kilburn) wheat and consequent contamination by the mycotoxin deoxynivalenol (DON) under UK weather conditions. Interactions of $P$. indica with an arbuscular mycorrhizal fungus (Funneliformis mosseae), fungicide application (Aviator Xpro) and low and high fertiliser levels were considered. $P$. indica application reduced FHB disease severity and incidence by $70 \%$. It decreased mycotoxin DON concentration of winter and spring wheat samples by $70 \%$ and $80 \%$ respectively. $P$. indica also increased above ground biomass, 1000 grain weight and total grain weight. $P$. indica reduced disease severity and increased yield in both high and low fertiliser levels. The effect of $P$. indica was compatible with $F$. mosseae and foliar fungicide application. $P$. indica did not have any effects on plant tissue nutrients. These results suggest that $P$. indica might be useful in biological control of Fusarium diseases of wheat.

\section{Introduction}

Fusarium crown rot (FCR) and head blight (FHB) are two of the most important diseases of wheat globally. The two most prevalent causal organisms are Fusarium culmorum and F. graminearum (Fernandez \& Chen, 2005). Fusarium spp. produce a range of mycotoxins that can accumulate in the grain and, if they enter the food chain, can cause a risk to human and animal health (Xu et al., 2008). The mycotoxin deoxynivalenol (DON), which is produced during head infection, has been identified as the most frequent contaminant associated with FHB in wheat (Bai \& Shaner, 2004). European Union legislation has set a legal limit for DON 
of $1250 \mu \mathrm{g} \mathrm{kg}^{-1}$ for cereals intended for human consumption (Anon, 2006), but even low level contamination of grain can reduce market prices or cause the grain to be rejected entirely (Bai \& Shaner, 2004). Fusarium species overwinter in soil and crop residues for several seasons. They survive as saprophytes on dead host tissues, especially if susceptible crops are planted in successive years. The most important sources of inoculum are ascospores from the sexual stage and macroconidia from the anamorph stage but chlamydospores and hyphal fragments can also act as sources of inoculum (Leplat et al., 2013). During warm, moist and windy environmental conditions the ascospores or macroconidia are dispersed by water-splash or air currents onto wheat heads and initiate infection of wheat spikes. Infections can occur as early as spike emergence, but the flowering stage or shortly after is considered the most vulnerable stage for Fusarium infection (Madgwick et al., 2011). No highly resistant commercial cultivars are yet available. Agronomic practices intended to reduce these diseases are only partially effective, because the necessary actions depend on the causal species and the environmental conditions, and the results are often unpredictable (Paulitz et al., 2002). Currently, control of Fusarium diseases relies on high inputs of fungicide in FHB-endemic regions (Mesterházy, 2003). Two factors are currently increasing the Fusarium problem in the UK. First, the UK is predicted to experience more often weather (UKCIP; www.ukcip.org.uk/) which will increase the risks of infection, colonisation, reproduction and dispersal of Fusarium diseases (West et al., 2012) leading to increased severity and incidence. Second, maize cultivation is increasing, leading to increased populations of $F$. graminearum; as maize debris is a potent source of inoculum of Fusarium (West et al., 2012).

Plant roots are associated with beneficial fungi in the majority of soils. For example, arbuscular mycorrhizal fungi (AMF), such as Funneliformis mosseae (=Glomus mosseae), are important soil microorganisms forming beneficial symbiotic associations with most land plants. AMF are 
obligate biotrophs which provide mineral nutrients, specifically phosphate and nitrogen, to their host plant in exchange for carbohydrates and therefore stimulate plant growth (Bucher, 2007, Schalamuk et al., 2011).

Piriformospora indica is a root endophyte with a wide host range belonging to the Sebacinaceae (Sebacinales, Basidiomycota). It was originally found in the Thar desert of Rajasthan, an arid region in India (Verma et al., 1998), which experiences extreme day-time heat and diurnal temperature fluctuations as well as extended drought. $P$. indica promotes plant growth, increases root and above ground biomass and final yield of a broad range of host plants, including many plants of economic importance (Shrivastava \& Varma, 2014) and helps plants to grow under temperature, water and physical stresses (Alikhani et al., 2013, Ghabooli et al., 2013). Evidence suggests that $P$. indica protects plants against pathogens of roots (caused by Fusarium culmorum, F. graminearum, Gaeumannomyces graminis var. tritici), stems (caused by Oculimacula Spp.) and leaves (caused by Blumeria graminis f.sp. tritici and B. graminis f.sp. hordei) under glasshouse and field conditions (Deshmukh \& Kogel, 2007, Ghahfarokhy et al., 2011, Harrach et al., 2013, Waller et al., 2005). Our previous work shows that $P$. indica association protected wheat seedlings from FCR damage in simulated UK autumn conditions (Rabiey et al., 2015).

The effect of some root associated fungi is to improve plant nutrient uptake (Miransari, 2010, Wu et al., 2011). For instance, AMF obtain fixed carbon compounds from host plants, while plants benefit from increased nutrient supply (Finlay, 2008). Research so far suggests that $P$. indica association improves plant mineral nutrient acquisition from the soil. It can mobilise and transport phosphorus, nitrogen and micronutrients from soil to the infected host plant via plant-fungal interfaces (Sherameti et al., 2005, Yadav et al., 2010). However, it is not yet clear if $P$. indica can increase nutrient uptake in all of its hosts. 
91 The present study investigated the effect of $P$. indica on Fusarium infection of parts of the host not directly colonised by $P$. indica. We tested the following hypotheses: $P$. indica would reduce damage to wheat grains caused by FHB and mycotoxin contamination; any effect of $P$. indica on FHB would be greater at low soil fertility levels as in AMF, such as F. mosseae (Nouri et al., 2015); $P$. indica application would be as effective as fungicide application; and $P$. indica would increase plant tissue nutrients. We scored FHB disease severity and incidence, analysed mycotoxin DON, yield parameters and nutrients level in wheat grown in pots with factorial combinations of inoculation with $F$. culmorum, $F$. graminearum, $P$. indica, or $F$. mosseae, foliar fungicide and low and high fertiliser application rates. Plants were grown outdoors.

\section{Materials and Methods}

\section{Fungal inoculation}

\section{Piriformospora indica}

$P$. indica was obtained from Dr. Patrick Schafer, Warwick University, UK and was grown on agar containing complex modified Aspergillus medium (CM medium). Inoculum prepared by the methods described by Rabiey et al. (2015). P. indica liquid culture containing an unquantified mixture of chlamydospores and mycelium was used for inoculation. The inoculum was mixed with soil at sowing time.

\section{Fusarium isolates}

Isolates of $F$. culmorum and $F$. graminearum (576 and 602.1) of UK origin were obtained from the School of Biological Sciences, University of Reading and Rothamsted Research Centre, UK, respectively. Inocula of $F$. culmorum were prepared by the methods described by Ghahfarokhy et al. (2011). 
113 Conidia of $F$. graminearum 576 and $F$. graminearum 602.1 were harvested from the surface of 114 sporulating PDA cultures in sterile distilled water so that the resulting suspension contained

$1151 \times 10^{6}$ spores $\mathrm{mL}^{-1}$.

\section{Funneliformis mosseae}

117 F. mosseae was obtained from Prof. Alan Gange, Royal Holloway/University of London. The

118 fungus was propagated on maize plants grown in a 3:1 mixture of steam sterilised compost 119 (John Innes Composts, BHGS Ltd, UK) and sand. After 3 months, the contents of each pot 120 (including compost and roots) were chopped on a sterilised surface and transferred into a zip121 lock bag and stored at $4{ }^{\circ} \mathrm{C}$ until required.

122 Plant materials and pot experiments

123 The effect of Piriformospora indica and Funneliformis mosseae on Fusarium crown rot and Fusarium head blight of winter wheat under low and high fertiliser regimes

Winter wheat seeds, cv. Battalion, were surface disinfected by rinsing for 2 mins in $20 \mathrm{~mL} \mathrm{~L}^{-1}$ (2\%) sodium hypochlorite (Fisher scientific, UK), followed by three rinses in sterilized distilled water, and germinated on damp filter paper in a Petri dish at room temperature under natural indoor light for 48 hours. No micro-organisms grew from a sample of seeds so treated and placed on PDA plates for one week. Eight germinated seeds per pot were planted in 12L pots at a depth of $2 \mathrm{~cm}$ in a mixture of 2 parts non-sterilised compost (No 2, John Innes Compost, BHGS Ltd, UK) and one part sand, mixed with 11 grams $\left(1 \mathrm{~g} \mathrm{~L}^{-1}\right)$ or 44 grams $\left(4 \mathrm{gL}^{-1}\right)$ of slow release fertiliser (8-9 months, Osmocote ${ }^{\circledR}$ Pro, the Scott Company, UK, contains $16 \%$ nitrogen, $11 \%$ phosphorus, $10 \%$ potassium, $2 \%$ magnesium oxide, $0.01 \%$ boron, $0.042 \%$ copper, $0.3 \%$ iron, $0.04 \%$ manganese, $0.015 \%$ molybdenum and $0.01 \%$ zinc) to provide wheat macro- and 
between each seed to simulate field spacing. Non-sterilised compost and sand were used to simulated field soil conditions.

In all experiments, pots were watered as necessary to maintain the compost moist, and the experimental area was surrounded by pots filled with sand to reduce edge effects on microclimate.

The experiment was carried out in the 2013-14 growing season at the University of Reading (grid ref: SU733719), under natural conditions. The experiment had 32 treatments with two replicates (giving $32 \mathrm{df}$ for error), distributed in two randomised blocks, with the following factorial combinations of treatments $= \pm$ P.indica, $\pm F$. mosseae, $\pm F$.culmorum (FCR), $\pm F$. graminearum (FHB) and \pm fertiliser $\left(1 \mathrm{~g} \mathrm{~L}^{-1}\right.$ or $\left.4 \mathrm{~g} \mathrm{~L}^{-1}\right)$. Inoculations with $P$. indica $(6 \mathrm{~g}$ liquid culture mixed with soil) and $F$. mosseae $(50 \mathrm{~g}, 20$ spores per $\mathrm{g}$, mixed with soil) and $F$. culmorum (6 g of prepared inocula mixed with soil) were performed at sowing and $F$. graminearum was applied at flowering. All disease symptoms, whether from inoculations or natural infections were recorded when appropriate, including Septoria leaf blotch and yellow rust.

In this experiment, extra nitrogen and sulphur fertiliser were applied in two split applications, with the first dose applied in late March and the second in late April, including $1.4 \mathrm{~g} \mathrm{~N} \mathrm{pot}^{-1}$ (over 2 splits) and $28 \mathrm{mg} \mathrm{S}$ pot $^{-1}$ (in one application). The first dose was made up of ammonium nitrate $(34.5 \% \mathrm{~N})$ and ammonium sulphate nitrate $\left(27 \% \mathrm{~N}, 30 \% \mathrm{SO}_{4}\right)$. The second dose was ammonium nitrate $(34.5 \% \mathrm{~N})$.

The effect of Piriformospora indica, Funneliformis mosseae and fungicide application on Fusarium head blight of spring wheat

Spring wheat seeds, cv. Paragon, were surface disinfected and pre-germinated as described above. Eight germinated seeds per pot were planted in 12L pots at a depth of $2 \mathrm{~cm}$ in non- 
sterilised compost and sand (2:1), mixed with 44 grams $\left(4 \mathrm{~g} \mathrm{~L}^{-1}\right)$ of slow release fertiliser as for winter wheat.

The experiment was carried out in the 2014 growing season. It had 16 treatments with three replicates, distributed in three randomised blocks, with the following factorial combinations of treatments: $\pm P$.indica, $\pm F$. mosseae $\pm F$. graminearum (FHB) and \pm fungicide. Inoculations with $P$. indica (6g liquid culture mixed with soil) and $F$. mosseae $(50 \mathrm{~g}, 20$ spores per $\mathrm{g}$ mixed with soil) were performed at sowing. The fungicide, Aviator Xpro (Bayer CropScience, UK) with active ingredients of prothioconazole (15.84\%) and bixafen $(7.43 \%)$, was applied at the concentration of $2 \mathrm{ml} \mathrm{L}^{-1}$, diluted with water, when flag leaf was fully emerged (Zadoks Growth Stage (GS) 39; T2; Zadoks et al. (1974)) and also 72 hours after plants were artificially sprayed with spore suspension of $F$. graminearum (GS 65; T3) at both stages for the selected treatments only. The fungicide Aviator Xpro exhibits both translaminar (within and across the leaf) and systemic movement (around the plant).

\section{The effect of Piriformospora indica on Fusarium head blight of different cultivars of} spring wheat

It is possible that some wheat cultivars benefit more than others from association with $P$. indica. In another experiment, the effect of $P$. indica on Fusarium head blight of spring wheat was assessed on 6 different spring wheat cultivars: Paragon, Mulika, Zircon (group 1), Granary, KWS Willow (group 2) and KWS Kilburn (group 4), chosen from HGCA recommended list for spring sowing and were supplied by KWS UK Ltd. Eight germinated seeds per pot were planted in 12L pots at a depth of $2 \mathrm{~cm}$ in a mixture of 2 parts non-sterilised compost and one part sand, mixed with 44 grams $\left(4 \mathrm{~g} \mathrm{~L}^{-1}\right)$ of slow release fertiliser (3-4 months, Osmocote ${ }^{\circledR}$ Pro). 
183 The experiment was done in the 2015 growing season. The experiment had 24 treatments with 184 three replicates, distributed in three randomised blocks, with the following factorial combinations of treatments: $\pm P$ indica, $\pm F$. graminearum (FHB), and 6 cultivars of spring wheat. Inoculations with $P$. indica (6 g liquid culture mixed with soil) was performed at sowing and $F$. graminearum was applied at flowering. All disease symptoms, whether from inoculations or natural infections, were recorded when appropriate including yellow rust and powdery mildew.

\section{Fusarium ear inoculation}

In all experiments, when most tillers of each pot were at mid-anthesis stage (GS 65), all tillers in the pot were sprayed with $1 \mathrm{~mL}$ of a 50:50 mixed conidia suspension of $F$. graminearum 576 and $F$. graminearum 602.1. In all experiments inoculation was done in a cloudy evening with rain afterward.

\section{Fusarium head blight visual disease assessment and yield determination}

Visual disease assessment, based on the percentage of infected spikelets per ear, was made two weeks after artificial inoculation on each of the treated ears from each pot. F.graminearum disease symptoms were recognized by pink fungal growth, brown-coloured lesions and premature bleaching of spikelets.

Plants were hand harvested at GS 92. The total above ground dry weight, total grain weight at 15\% moisture content, 1000 grain weight (TGW), harvest index (total grain weight/total above grain weight), number of ears and root dry weight were measured.

\section{Mycotoxin Analysis}

Determination of mycotoxin DON in all samples from the winter and spring experiments was performed using ELISA testing by RomerLabs (Romer Labs Ltd, UK). 
207 Winter wheat seeds, cv. Battalion, were surface disinfected and pre-germinated. Eight seeds per pot were planted in $12 \mathrm{~L}$ pots at a depth of $2 \mathrm{~cm}$ in 2 parts non-sterilised and one part sand, mixed with 11 grams $\left(1 \mathrm{~g} \mathrm{~L}^{-1}\right)$ or 44 grams $\left(4 \mathrm{~g} \mathrm{~L}^{-1}\right)$ of slow release fertiliser (8-9 months,

210 Osmocote ${ }^{\circledR}$ Pro). The experiment was carried out in the 2014/15 growing season. The experiment had 8 treatments with three replicates, distributed in three randomised blocks, with the following factorial combinations of treatments: $\pm P$ indica, $\pm F$. mosseae, and \pm fertiliser (1 $\mathrm{g} \mathrm{L}^{-1}$ or $\left.4 \mathrm{~g} \mathrm{~L}^{-1}\right)$. Inoculations with $P$. indica (6 $\mathrm{g}$ liquid cultures mixed with soil) and $F$. mosseae (50 g, 20 spores per g mixed with soil) were done at the time of sowing. Around $200 \mathrm{~g}$ leaf materials of each treatment at GS 27-29 (tillering, main shoot with 7-9 or more tillers) were sent for analysis in the first week of April 2015. The plant tissue analysis included total nitrogen $(\mathrm{N})$ and sulphur $(\mathrm{S})$ with $\mathrm{N}: \mathrm{S}$ ratio, total phosphorus $(\mathrm{P})$, potassium $(\mathrm{K})$, magnesium $(\mathrm{Mg})$, calcium $(\mathrm{Ca})$, copper $(\mathrm{Cu})$, zinc $(\mathrm{Zn})$, Iron $(\mathrm{Fe})$ and Boron $(\mathrm{B})$.

\section{Weather conditions during 2013-15}

Winter 2013/14 was an exceptionally stormy season, with at least 12 major winter storms affecting the UK. Mean temperatures and total rainfall over Reading were well above the longterm average (Nov-Mar 2013-14 average $7.1^{\circ} \mathrm{C}$ ). Following this, the weather of spring and summer 2014 was warm (April-June 2014 average $13.5^{\circ} \mathrm{C}$ ) with rainfall above the average. The weather of Sep-Nov 2014 was exceptionally warm (average $12.7^{\circ} \mathrm{C}$ ) with all months warmer than average and the number of air frosts well below average. Rainfall was slightly above average. Dec-Mar 2014/15 was sunny with mean temperature $\left(5.6^{\circ} \mathrm{C}\right)$ near average. Rainfall totals were slightly below average. April-Jun 2015 mean temperature $\left(12.5^{\circ} \mathrm{C}\right)$ was, close to average, with rainfall well below the average. (www.met.reading.ac.uk/weatherdata). 


\section{Statistical analysis of experiments}

230 ANOVA was used to analyse all data using GenStat 17th ed, (VSN, UK) with appropriate

231 blocking. Where judged necessary from residual plots, data were $\log _{10}$ or square root

232 transformed to stabilize the residual variance and aid interpretation.

233 Results

\section{Emergence rate}

235 The emergence rate of cv. Battalion (winter 2013), cv. Paragon (spring 2014) and the average

236 of six cultivars of spring wheat seedlings (spring 2015) from control treatments 14 days after

237 sowing was $90 \%, 98 \%$ and $95 \%$ respectively. F. culmorum application at sowing time reduced

238 the emergence rate by $10 \%(\mathrm{P}=0.04)$. There were no other significant differences between

239 treatments.

240 Fusarium head blight disease severity and incidence

241 FHB disease severity of winter wheat cv. Battalion was assessed two weeks after artificial

242 inoculation at GS65. The main effects of fungicide and inoculation were large and significant,

243 but interactions between them and with $P$. indica were also important. Third and fourth order

244 interactions were not significant. Inoculation of ears with Fusarium increased the disease

245 severity and incidence significantly $(\mathrm{P}<0.001)$ compared to non-inoculated samples, but there

246 was also some natural background infection of Fusarium spp. present. F. culmorum application

247 at the time of sowing did not have a significant effect on FHB disease severity or incidence.

248 FHB severity and incidence in pots inoculated with $P$. indica (at sowing) and $F$. graminearum

249 (at flowering) was reduced by $70 \%$ (severity interaction $\mathrm{P}=0.004$; incidence interaction

$250 \mathrm{P}=0.005$ ), compared to $F$. graminearum inoculated pots. Disease severity and incidence were

251 higher in the low fertilisation level than the high level (main effect $\mathrm{P}<0.001$ ). F. mosseae

252 reduced severity and incidence of FHB, but this effect was not additive to that of $P$. indica, so 

information 1).
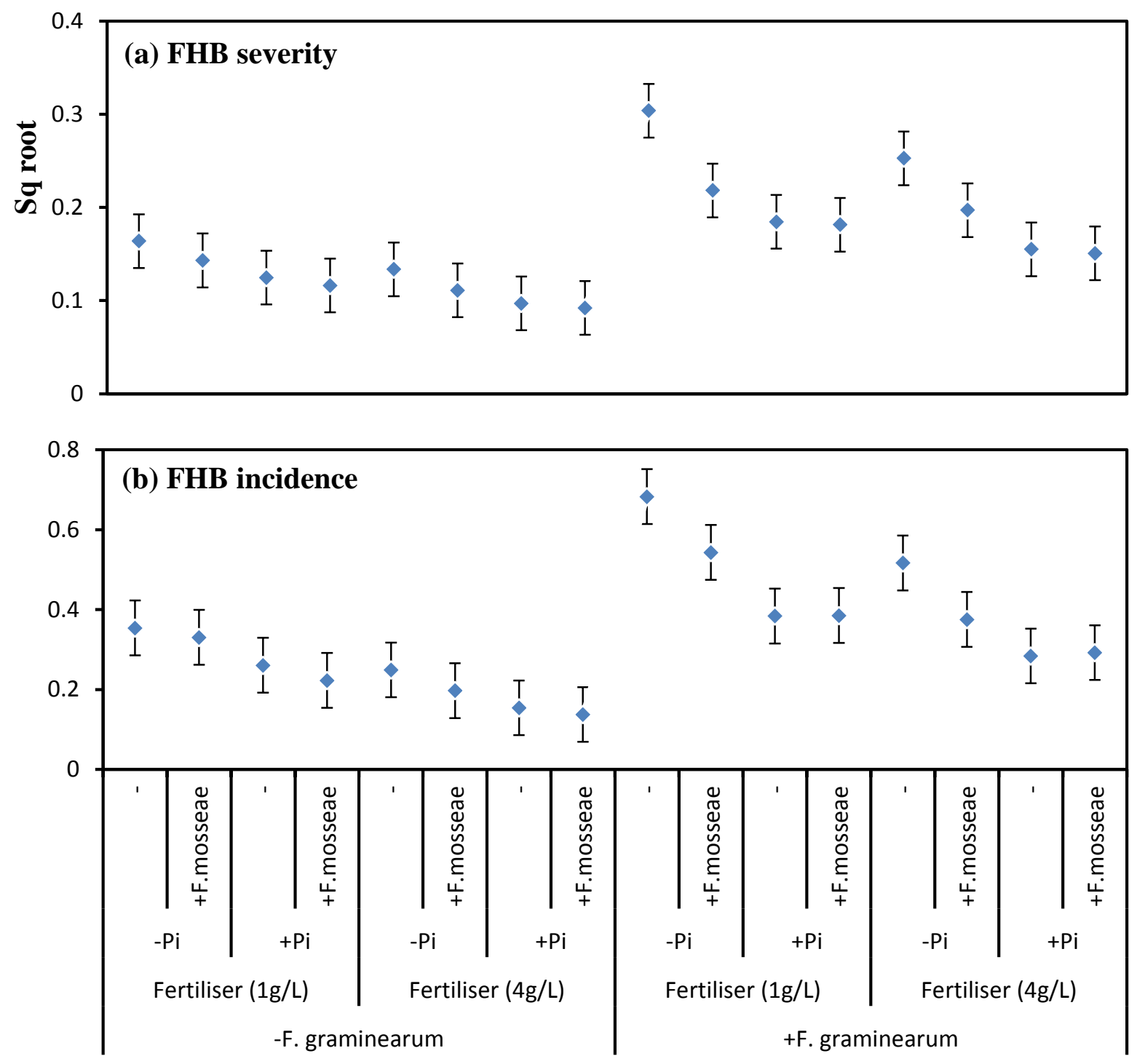

Fig 1. The effect of Piriformospora indica (Pi) and Funneliformis mosseae under low $\left(1 \mathrm{~g} \mathrm{~L}^{-1}\right)$ and high $\left(4 \mathrm{~g} \mathrm{~L}^{-1}\right)$ fertiliser levels (Osmocote ${ }^{\circledR}$ Pro slow release fertiliser) on Fusarium head blight (FHB) disease severity and incidence of winter wheat (cv. Battalion), recorded at two weeks after artificial inoculation with Fusarium graminearum. (a) FHB disease severity, s.e.d $=0.02$; d.f $=31$ (data were square root transformed); (b) FHB disease incidence, s.e.d = 0.05; d.f $=31$; Each point represents mean \pm 2 SEM. 
265 In spring wheat cv. Paragon, inoculation of ears with Fusarium spores significantly increased 266 the disease severity and incidence of FHB (main effect of inoculation $\mathrm{P}<0.001$ ), but there was 267 also some natural background infection of Fusarium spp. (Fig. 2 a,b). The application of 268 fungicide following F. graminearum inoculation reduced FHB severity by 80\% 269 (fungicide.FHB interaction $\mathrm{P}=0.04$ ). $P$. indica soil inoculation resulted in a reduction in FHB 270 severity, but the effect was only marginally significant ( $P$. indica. FHB interaction $\mathrm{P}=0.08$; Fig. 2712 a,b, supporting information 2).

272 

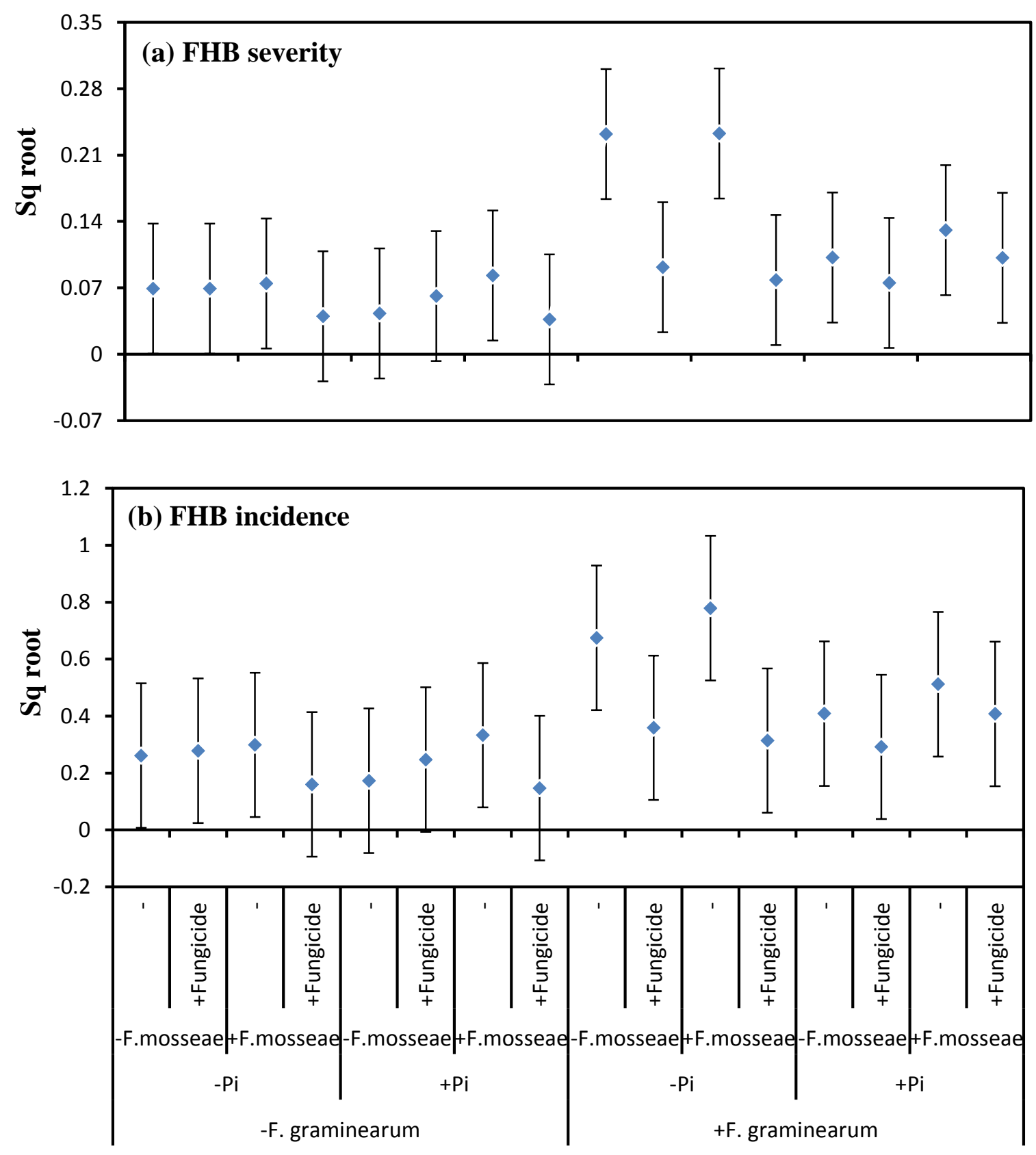

291 Fig 2. The effect of Piriformospora indica (Pi), Funneliformis mosseae and fungicide Aviator 292 Xpro on Fusarium head blight (FHB) disease severity and incidence of spring wheat (cv. 293 Paragon), recorded at two weeks after artificial inoculation with Fusarium graminearum. (a) 294 FHB disease severity, s.e.d $=0.05$, d.f $=30$ (data were square root transformed); (b) FHB 295 disease incidence, s.e.d $=0.18$, d.f $=30$, (data were square root transformed); Each point 296 represents mean \pm 2 SEM. 
299 Ears inoculation of six cultivars of spring wheat with $F$. graminearum spores significantly

300 increased the disease severity and incidence of FHB (main effect of inoculation $\mathrm{P}<0.001$ ), but

301 there was also some natural background infection of Fusarium spp. (Fig 3 a,b). FHB severity

302 and incidence in pots inoculated with $P$. indica (at sowing) and F. graminearum (at flowering)

303 was reduced by around $80 \%$ (severity $P$. indica. FHB interaction $\mathrm{P}<0.001$; incidence

304 interaction $\mathrm{P}=0.02$ ), compared to $F$. graminearum inoculated pots (Fig 3 a,b, supporting 305 information 3).

306
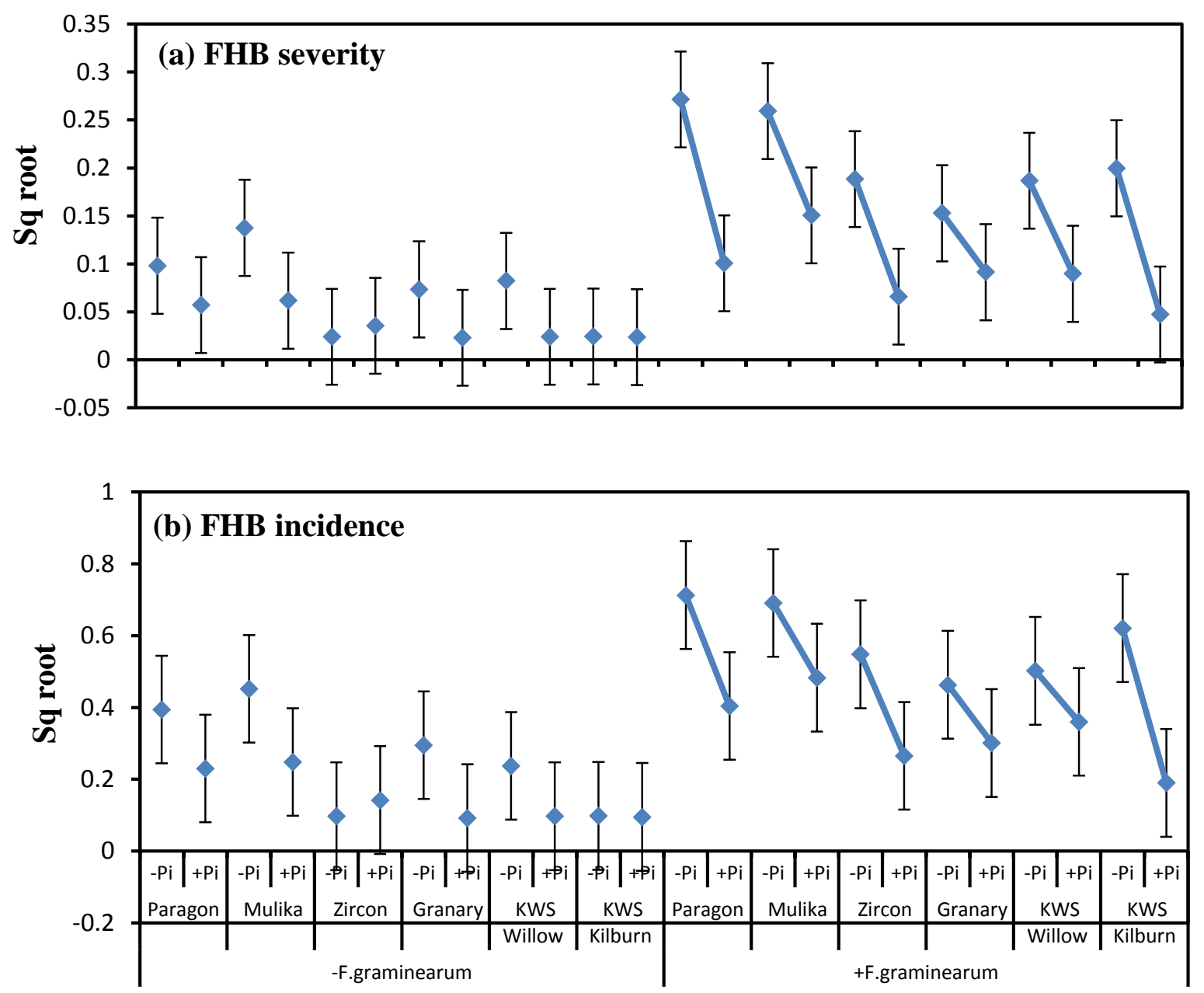

308 Fig 3. The effect of Piriformospora indica (Pi) on Fusarium head blight (FHB) disease severity 309 and incidence of six cultivars of spring wheat (cv. Paragon, Mulika, Zircon, Granary, KWS 310 Willow and KWS Kilburn), recorded at two weeks after artificial inoculation with Fusarium 
graminearum. (a) FHB disease severity, s.e.d $=0.04$; d.f $=46$; (b) FHB disease incidence s.e.d $=0.1$; .f $=46$; (data were square root transformed). Each point represents mean \pm 2 SEM.

\section{Mycotoxin DON analysis}

ELISA testing could only detect DON level of above the limit of detection. For both winter and spring wheat samples with no Fusarium head inoculation, DON concentrations were below the limit of detection $\left(<250 \mu \mathrm{g} \mathrm{kg}^{-1}\right)$. We therefore restricted the analysis to those samples from plants which were artificially inoculated with $F$. graminearum and considered those lower than the limit of detection as $250 \mu \mathrm{g} \mathrm{kg}^{-1}$. The following results concern $F$. graminearum-inoculated samples only, in the cv. Battalion in 2014: P. indica application reduced DON concentrations by $70 \%$ at low fertilisation and $50 \%$ at high fertilisation (Fig 4a; P. indica. fertiliser interaction $\mathrm{P}<0.001)$, to levels close to the limit of detection. In the absence of $P$. indica, DON concentrations were $70 \%$ higher at low fertilisation (fertiliser main effect $\mathrm{P}=0.005$ ) than high fertilisation. DON concentrations were higher in the samples inoculated at sowing with $F$. culmorum $(\mathrm{P}<0.001)$; however, $P$. indica reduced DON concentrations in these samples to below the limit of detection $(\mathrm{P}<0.001)$. F. mosseae had no main effect $(\mathrm{P}=0.5)$ and no significant interactions (Fig. 4a, supporting information 4).

In the cv. Paragon spring wheat samples in 2014 inoculation with $F$. graminearum significantly increased DON concentrations (main effect $\mathrm{P}<0.001$ ). The following results concern $F$. graminearum-inoculated samples only: $P$. indica application (main effect $\mathrm{P}=0.01$ ) reduced DON concentrations by $80 \%$ (Fig 4b). Fungicide application (main effect $\mathrm{P}=0.001$ ) also reduced the mycotoxin concentrations by $70 \%$, but the effect was not additional to that of $P$. indica (interaction $\mathrm{P}=0.03$ ). $F$. mosseae had no effect on average (main effect, $\mathrm{P}=0.5$ ) but had a significant interaction with $P$. indica $(\mathrm{P}=0.009)$ : without $P$. indica, $F$. mosseae reduced DON 
335

336

337

338

339

340

341

342

343

344

345

346

347

348

349

350

351

352

353

354

355

356

357

347

348

by roughly $50 \%$, but in the presence of $P$. indica, F. mosseae increased DON by about $50 \%$ (Fig. 4b, supporting information 5).

In 2015, inoculation of six cultivars of spring wheat samples with $F$. graminearum significantly increased DON concentrations (main effect $\mathrm{P}<0.001$ ); very few positive samples were found in the uninoculated pots, and with low levels of contamination. The following results concern F. graminearum-inoculated samples only: The cultivars differed in mycotoxin DON concentration $(\mathrm{P}<0.001)$. P. indica application reduced DON concentration by around $90 \%$ (main effect $\mathrm{P}<0.001)$. P. indica reduced DON concentration in all cultivars, with an interaction arising because cv. KWS Willow and cv. Granary had low concentrations of DON even in non$P$. indica treated pots (interaction $\mathrm{P}=0.002$, Fig 4c, supporting information 6). FHB severity was well correlated to DON ( $r=0.7)$. Both FHB severity and DON were weakly related to yield, but not to root-shoot ratio, above ground biomass or root biomass. 

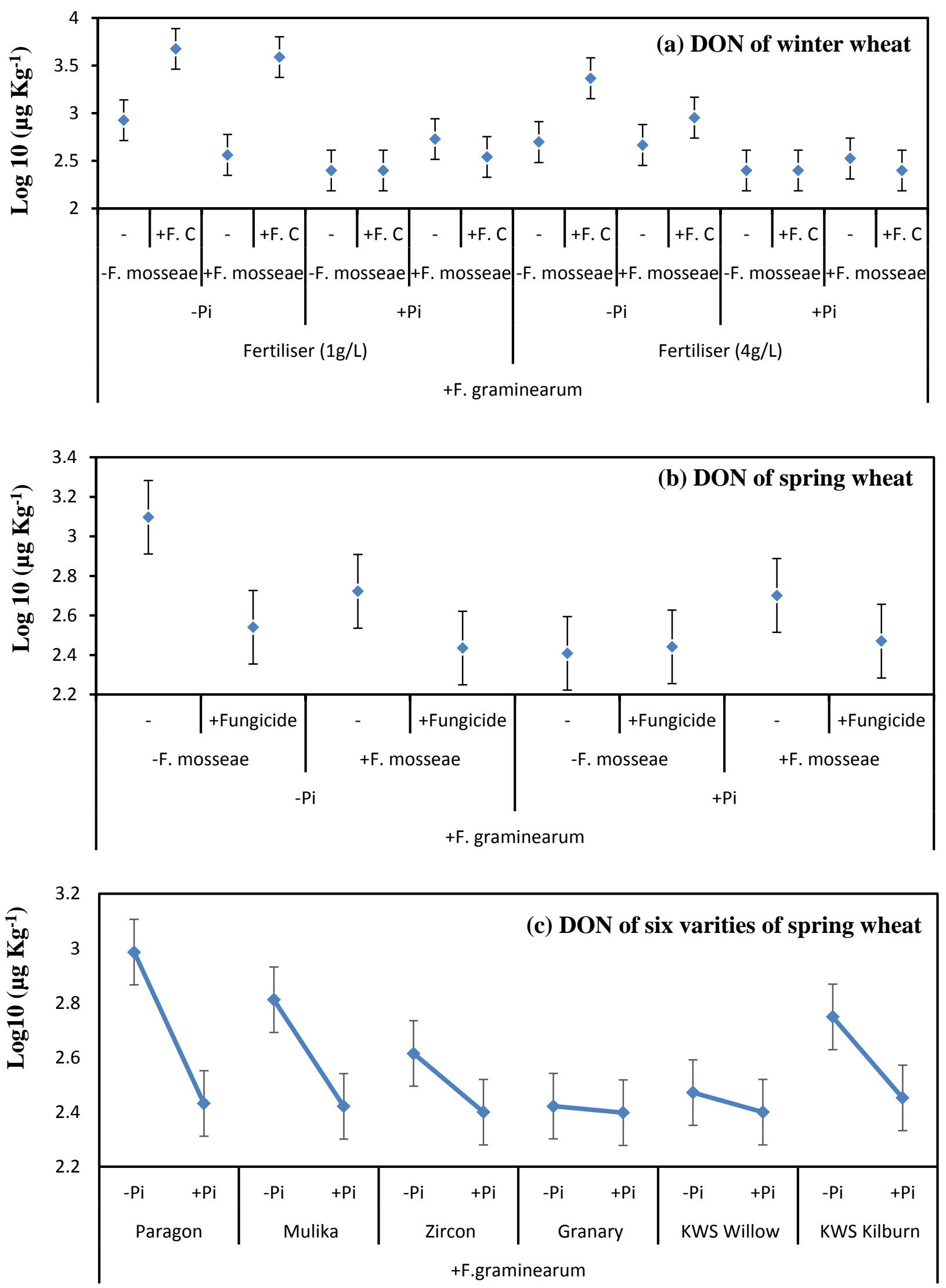
Fig 4. The effect of Piriformospora indica (Pi), Funneliformis mosseae and fungicide Aviator Xpro, under low $\left(1 \mathrm{~g} \mathrm{~L}^{-1}\right)$ and high $\left(4 \mathrm{~g} \mathrm{~L}^{-1}\right)$ fertiliser levels (Osmocote ${ }^{\circledR}$ Pro slow release fertiliser) on Fusarium mycotoxin deoxynivalenol (DON) of winter and spring wheat grain samples. (a) DON of winter wheat samples (cv. Battalion), s.e.d $=0.15$, d.f $=15$; (b) DON of spring wheat samples (cv. Paragon), s.e.d $=0.13$, d.f $=14$; (c) DON of six cultivars of spring wheat samples (cv. Paragon, Mulika, Zircon, Granary, KWS Willow and KWS Kilburn), s.e.d $=0.08$, d.f. $=22 ;$ (data were $\log _{10}$ transformed); Each point represents mean \pm 2 SEM; (F.c: $F$. culmorum).

\section{Final harvest results}

\section{Winter wheat cv. Battalion, 2014}

Above ground biomass: F. mosseae increased the above ground biomass in the presence of $F$. culmorum by $17 \%$ at high fertilisation and by $10 \%$ at low fertilisation, compared to $F$. culmorum-inoculated samples $(F$. mosseae. $F$. culmorum interaction $\mathrm{P}<0.001)$. P. indica inoculation increased biomass on average (main effect $\mathrm{P}=0.06$ ). Its combination with $F$. mosseae increased the above ground biomass in the presence of $F$. graminearum by $25 \%$ at low fertilisation ( $P$. indica. $F$. mosseae. $F$. graminearum interaction $P=0.008$ ), compared to samples inoculated with $F$. graminearum alone. The co-inoculation increased biomass also in plants inoculated with $F$. culmorum, by $15 \%$ at low fertilisation and $34 \%$ at high fertilisation (P. indica. F. mosseae. F. culmorum interaction $\mathrm{P}=0.07)$. At low fertilisation, in the presence of F. graminearum, F. mosseae increased the above ground biomass by $30 \%$ (F. mosseae, fertiliser. F. graminearum interaction $\mathrm{P}=0.001)$, compared to $F$. graminearum-inoculated samples at low fertilisation. F. culmorum application at sowing time reduced the above ground weight by $7 \%$, but the effect could have been chance $(\mathrm{P}=0.09)$.

Root biomass: Roots were heavier at high fertilisation than low fertilisation (main effect $\mathrm{P}<0.001)$. $P$. indica application increased the root weight by $55 \%$ at both low and high fertilisation (main effect $\mathrm{P}<0.001$ ), compared to non- $P$. indica inoculated samples. The co- 
389 inoculation of $F$. mosseae with $P$. indica also increased the root weight by $52 \%$ at low 390 fertilisation and $37 \%$ at high fertilisation ( $P$. indica. F. mosseae $\mathrm{P}<0.001$ ). F. culmorum 391 reduced the root weight by $40 \%$ at both low and high fertilisation (interaction $\mathrm{P}<0.001$ ). This 392 reduction was smaller when $P$. indica $(\mathrm{P}=0.01)$ or $F$. mosseae $(\mathrm{P}=0.01)$ were also applied.

393 Yield: F. mosseae at low fertilisation increased the total grain weight by $5 \%$, but at high 394 fertilisation it decreased the weight by $20 \%$ ( $F$. mosseae. fertiliser interaction $\mathrm{P}=0.03$ ), compared to non-F. mosseae-inoculated samples. The combination of $P$. indica and $F$. mosseae increased the total grain weight by $60 \%$ in the presence of $F$. graminearum ( $P$. indica. F.mosseae. $F$. graminearum interaction $\mathrm{P}=0.09$ ) at low fertilisation level, compared to $F$. graminearum-inoculated samples. The combination of $P$. indica and $F$. mosseae increased the total grain weight in the presence of $F$. culmorum at both low and high fertilisation $(P$. indica. F.mosseae. F. culmorum interaction $\mathrm{P}=0.05)$.

TGW: P. indica application increased 1000 grain weight (TGW) by $8 \%$ at low fertility (main effect $\mathrm{P}=0.02)$. The application of $F$. graminearum reduced TGW by $10 \%(\mathrm{P}=0.06)$ at both low and high fertilisation. However, $P$. indica maintained TGW in the presence of $F$. graminearum at low fertilisation ( $P$. indica. $F$. graminearum interaction $\mathrm{P}=0.04$ ). The combination of $P$. indica and $F$. mosseae increased TGW at high fertilisation, but not at low fertilisation $(P$. indica. F. mosseae. fertiliser interaction $\mathrm{P}=0.008)$.

Harvest index

408 : There were no significant differences among treatments for harvest index.

409 Ears: Fertilisation increased the number of ears per pot (main effect $\mathrm{P}=<0.001$ ). The combination of $P$. indica and $F$. mosseae increased the number of ears at both low and high

411 fertilisation ( $P$. indica. $F$. mosseae. fertiliser interaction $\mathrm{P}=0.02$ ), compared to non- $P$. indica412 inoculated samples (table 1 \& supporting information 1). 
413 Table 1. Final harvest results of winter wheat samples (cv. Battalion) inoculated with 414 Piriformospora indica (Pi), Funneliformis mosseae, Fusarium culmorum (F. c; at sowing time) 415 and $F$. graminearum (F. g; at flowering time) under low $\left(1 \mathrm{~g} \mathrm{~L}^{-1}\right)$ and high $\left(4 \mathrm{~g} \mathrm{~L}^{-1}\right)$ fertiliser 416 levels (Osmocote ${ }^{\circledR}$ Pro slow release fertiliser; d.f. $=31$ ).

\begin{tabular}{|c|c|c|c|c|c|c|c|c|c|c|}
\hline Fertiliser & P.indica & F.g & F.mosseae & F.c & $\begin{array}{c}\text { Total } \\
\text { above } \\
\text { ground } \\
\text { weight } \\
\text { (g) }\end{array}$ & $\begin{array}{c}\text { Root } \\
\text { weight }\end{array}$ & $\begin{array}{c}\text { Total } \\
\text { grain } \\
\text { weight } \\
\text { per pot } \\
\text { (g) } \\
\end{array}$ & $\begin{array}{c}1000 \\
\text { grain } \\
\text { weight } \\
(\mathrm{g})\end{array}$ & $\begin{array}{l}\text { Harvest } \\
\text { index }\end{array}$ & $\begin{array}{c}\text { no of } \\
\text { ears per } \\
\text { pot } \\
(\log 10)\end{array}$ \\
\hline \multirow{17}{*}{$1 \mathrm{~g} / \mathrm{L}$} & \multirow{8}{*}{-} & \multirow{4}{*}{-} & \multirow{2}{*}{ - } & - & 243 & 23 & 78 & 68 & 0.3 & 1.4 \\
\hline & & & & + & 227 & 16 & 77 & 66 & 0.3 & 1.4 \\
\hline & & & \multirow{2}{*}{+} & - & 264 & 21 & 82 & 71 & 0.3 & 1.4 \\
\hline & & & & + & 251 & 27 & 84 & 70 & 0.3 & 1.4 \\
\hline & & \multirow{4}{*}{+} & \multirow{2}{*}{-} & - & 204 & 21 & 57 & 60 & 0.3 & 1.4 \\
\hline & & & & + & 195 & 17 & 62 & 63 & 0.3 & 1.4 \\
\hline & & & \multirow{2}{*}{+} & - & 266 & 27 & 83 & 69 & 0.3 & 1.4 \\
\hline & & & & + & 274 & 33 & 79 & 67 & 0.3 & 1.4 \\
\hline & \multirow{9}{*}{+} & \multirow{5}{*}{-} & & mean & 241 & 23 & 75 & 67 & 0.3 & 1.4 \\
\hline & & & \multirow{2}{*}{-} & - & 272 & 34 & 85 & 73 & 0.3 & 1.4 \\
\hline & & & & + & 217 & 38 & 63 & 68 & 0.3 & 1.3 \\
\hline & & & \multirow[b]{2}{*}{+} & - & 257 & 35 & 83 & 67 & 0.3 & 1.4 \\
\hline & & & & + & 261 & 34 & 90 & 68 & 0.3 & 1.4 \\
\hline & & & \multirow[b]{2}{*}{-} & - & 247 & 28 & 77 & 66 & 0.3 & 1.3 \\
\hline & & & & + & 221 & 35 & 65 & 73 & 0.3 & 1 \\
\hline & & + & \multirow{2}{*}{+} & - & 257 & 32 & 92 & 68 & 0.4 & 1.4 \\
\hline & & & & + & 276 & 32 & 88 & 69 & 0.3 & 1.4 \\
\hline \multirow{18}{*}{$4 \mathrm{~g} / \mathrm{L}$} & \multirow{9}{*}{-} & \multirow{5}{*}{-} & & mean & 251 & 34 & 80 & 69 & 0.3 & 1.3 \\
\hline & & & \multirow{2}{*}{-} & - & 336 & 27 & 120 & 69 & 0.4 & 2 \\
\hline & & & & + & 276 & 19 & 95 & 67 & 0.3 & 1.6 \\
\hline & & & \multirow[b]{2}{*}{+} & - & 303 & 38 & 96 & 71 & 0.3 & 1.7 \\
\hline & & & & + & 326 & 34 & 94 & 68 & 0.3 & 2 \\
\hline & & & \multirow{2}{*}{-} & - & 307 & 31 & 89 & 64 & 0.3 & 1.6 \\
\hline & & & & + & 277 & 18 & 93 & 69 & 0.3 & 2 \\
\hline & & + & \multirow{2}{*}{+} & - & 305 & 38 & 110 & 65 & 0.4 & 1.7 \\
\hline & & & & + & 298 & 32 & 92 & 67 & 0.3 & 1.7 \\
\hline & \multirow{9}{*}{+} & & & mean & 304 & 30 & 99 & 68 & 0.3 & 1.8 \\
\hline & & & \multirow{2}{*}{ - } & - & 317 & 42 & 125 & 68 & 0.4 & 1.7 \\
\hline & & & & + & 281 & 37 & 94 & 69 & 0.3 & 1.6 \\
\hline & & - & \multirow{2}{*}{+} & - & 301 & 37 & 102 & 71 & 0.3 & 1.6 \\
\hline & & & & + & 372 & 37 & 129 & 71 & 0.3 & 1.7 \\
\hline & & & & - & 380 & 41 & 122 & 65 & 0.3 & 1.6 \\
\hline & & + & & + & 316 & 38 & 97 & 69 & 0.3 & 2 \\
\hline & & + & & - & 266 & 37 & 81 & 70 & 0.3 & 1.6 \\
\hline & & & + & + & 297 & 39 & 92 & 68 & 0.3 & 2 \\
\hline & & & & mean & 316 & 39 & 105 & 69 & 0.3 & 1.7 \\
\hline & & & & s.e.d & 24 & 3.09 & 17.3 & 3.07 & 0.05 & 0.05 \\
\hline
\end{tabular}


418 Spring wheat cv. Paragon, 2014

419 The application of $P$. indica increased total above ground weight by $16 \%$ (main effect $\mathrm{P}=0.05$ ),

420 root weight by $20 \%$ (main effect $\mathrm{P}=0.02$ ), total grain weight by $23 \%$ (main effect $\mathrm{P}=0.02$ ),

421 TGW by $23 \%$ (main effect $\mathrm{P}=0.08$ ), harvest index by $8 \%$ (main effect $\mathrm{P}=0.07$ ), and number of 422 ears by $12 \%$ (main effect $\mathrm{P}=0.003$ ), compared to samples without $P$. indica. The interaction of $423 P$. indica with $F$. graminearum increased total grain weight of $F$. graminearum-inoculated 424 samples by $54 \%(\mathrm{P}=0.08)$ and harvest index by $13 \%(\mathrm{P}=0.07)$. Also, the combination of $P$. 425 indica, F. mosseae and fungicide increased total above ground weight $(\mathrm{P}=0.03)$, total grain 426 weight $(\mathrm{P}=0.003)$, TGW $(\mathrm{P}=0.01)$, harvest index $(\mathrm{P}=0.009)$ and number of ears $(\mathrm{P}=0.003)$ 427 (Table $2 \&$ supporting information 2).

428

429

430

431

432

433

434

435

436

437

438

439

440

441 
Table 2. Final harvest results of spring wheat samples (cv. Paragon) inoculated with 443 Piriformospora indica (Pi), Funneliformis mosseae (at sowing time), Fusarium graminearum 444 (F. g; at flowering time) and fungicide Aviator Xpro (at growth stage 39 and 72 hours after 445 artificial inoculation at flowering time) (d.f. $=26)$.

\begin{tabular}{|c|c|c|c|c|c|c|c|c|c|}
\hline P. indica & F.g & F.mosseae & Fungicide & $\begin{array}{c}\text { Total } \\
\text { above } \\
\text { ground } \\
\text { weight } \\
(\mathrm{g})\end{array}$ & $\begin{array}{c}\text { Root } \\
\text { weight } \\
\text { (g) }\end{array}$ & $\begin{array}{c}\text { Total } \\
\text { grain } \\
\text { weight } \\
\text { per pot } \\
(\mathrm{g})\end{array}$ & $\begin{array}{c}1000 \\
\text { grain } \\
\text { weight } \\
(\mathrm{g})\end{array}$ & $\begin{array}{c}\text { Harvest } \\
\text { index }\end{array}$ & $\begin{array}{c}\text { no of } \\
\text { ears per } \\
\text { pot } \\
(\log 10)\end{array}$ \\
\hline \multirow{8}{*}{ - } & \multirow{4}{*}{-} & \multirow{2}{*}{-} & - & 193 & 23 & 73 & 43 & 0.4 & 39 \\
\hline & & & + & 229 & 28 & 103 & 52 & 0.5 & 41 \\
\hline & & \multirow{2}{*}{+} & - & 212 & 24 & 98 & 50 & 0.5 & 39 \\
\hline & & & + & 201 & 24 & 79 & 46 & 0.4 & 35 \\
\hline & \multirow{4}{*}{+} & \multirow{2}{*}{-} & - & 183 & 21 & 62 & 38 & 0.3 & 36 \\
\hline & & & + & 199 & 22 & 83 & 45 & 0.4 & 38 \\
\hline & & \multirow{2}{*}{+} & - & 213 & 29 & 86 & 50 & 0.4 & 38 \\
\hline & & & + & 214 & 30 & 90 & 45 & 0.4 & 35 \\
\hline \multirow{9}{*}{+} & & & mean & 206 & 25 & 84 & 46 & 0.4 & 38 \\
\hline & & \multirow{2}{*}{-} & - & 225 & 28 & 89 & 53 & 0.4 & 44 \\
\hline & & & + & 205 & 28 & 91 & 47 & 0.5 & 40 \\
\hline & & \multirow{2}{*}{+} & - & 205 & 29 & 82 & 46 & 0.4 & 39 \\
\hline & & & + & 232 & 28 & 102 & 47 & 0.4 & 41 \\
\hline & \multirow{4}{*}{+} & & - & 217 & 28 & 96 & 51 & 0.4 & 40 \\
\hline & & & + & 204 & 28 & 91 & 47 & 0.4 & 37 \\
\hline & & \multirow{2}{*}{+} & - & 236 & 28 & 95 & 51 & 0.4 & 40 \\
\hline & & & + & 226 & 25 & 108 & 48 & 0.5 & 39 \\
\hline & & & mean & 219 & 28 & 94 & 49 & 0.4 & 40 \\
\hline & & & s.e.d & 18.5 & 2.8 & 10.9 & 4.1 & 0.04 & 2.01 \\
\hline
\end{tabular}

447 Six cultivars of spring wheat, 2015

448 Averaged over other treatments, the cultivars of spring wheat differed in above ground biomass

$449(\mathrm{P}=0.02)$, root weight $(\mathrm{P}=0.09)$, total grain weight $(\mathrm{P}=0.001)$, and the number of ears per pot

$450 \quad(\mathrm{P}<0.001)$. Averaged over cultivars $P$. indica inoculation increased the above ground biomass

451 ( $\mathrm{P}<0.002)$, root weight $(\mathrm{P}=0.002)$, total grain weight $(\mathrm{P}<0.001)$, TGW $(\mathrm{P}<0.001)$, harvest

452 index $(\mathrm{P}<0.001)$ and the number of ears per pot $(\mathrm{P}=0.002) . F$. graminearum application at

453 flowering reduced the above ground biomass $(\mathrm{P}=0.06)$, total grain weight $(\mathrm{P}<0.001)$, and

454 harvest index $(\mathrm{P}=0.03)$ of all cultivars. In the presence of $F$. gramineraum, $P$. indica inoculation 
455 increased the above ground biomass and TGW (P. indica.F. graminearum interaction $\mathrm{P}=0.04$

456 and $\mathrm{P}=0.03$, respectively). There was no interaction between $P$. indica or $F$. graminearum with 457 cultivars (Table 3 \& supporting information 3 ).

\section{8}

459

460

461

462

463

464

465

466

467

468

469

470

471

472

473

474

475

476

477

478 
479 Table 3. Final harvest results of six cultivars of spring wheat samples (cv. Paragon, Mulika, 480 Zircon, Granary, KWS Willow and KWS Kilburn) inoculated with Piriformospora indica (at 481 sowing time), and Fusarium graminearum (F. g; at flowering time, d.f. = 46).

\begin{tabular}{|c|c|c|c|c|c|c|c|c|}
\hline P.indica & F.g & $\begin{array}{l}\text { Spring } \\
\text { wheat } \\
\text { cultivars }\end{array}$ & $\begin{array}{l}\text { Total above } \\
\text { ground } \\
\text { weight }(\mathrm{g})\end{array}$ & $\begin{array}{l}\text { Root } \\
\text { weight } \\
\text { (g) }\end{array}$ & $\begin{array}{c}\text { Total grain } \\
\text { weight per } \\
\text { pot }(\mathrm{g})\end{array}$ & $\begin{array}{c}1000 \\
\text { grain } \\
\text { weight } \\
(\mathrm{g})\end{array}$ & $\begin{array}{c}\text { Harvest } \\
\text { index }\end{array}$ & $\begin{array}{l}\text { No of } \\
\text { ears }\end{array}$ \\
\hline \multirow{13}{*}{ - } & \multirow{7}{*}{ - } & Paragon & 267 & 18.6 & 82 & 45 & 0.3 & 51 \\
\hline & & Mulika & 267 & 15.3 & 94 & 47 & 0.4 & 52 \\
\hline & & Zircon & 289 & 17.9 & 103 & 48 & 0.4 & 66 \\
\hline & & Granary & 250 & 16.2 & 87 & 46 & 0.4 & 60 \\
\hline & & $\begin{array}{c}\text { KWS } \\
\text { Willow }\end{array}$ & 283 & 14.8 & 105 & 45 & 0.4 & 59 \\
\hline & & $\begin{array}{c}\text { KWS } \\
\text { Kilburn }\end{array}$ & 257 & 16.1 & 93 & 44 & 0.4 & 62 \\
\hline & & mean & 269 & 16.5 & 94 & 46 & 0.4 & 58 \\
\hline & \multirow{6}{*}{+} & Paragon & 201 & 17.2 & 61 & 39 & 0.3 & 54 \\
\hline & & Mulika & 228 & 16.8 & 72 & 43 & 0.3 & 53 \\
\hline & & Zircon & 245 & 17.4 & 88 & 45 & 0.4 & 61 \\
\hline & & Granary & 219 & 15.7 & 74 & 44 & 0.3 & 60 \\
\hline & & $\begin{array}{c}\text { KWS } \\
\text { Willow }\end{array}$ & 257 & 17.4 & 71 & 41 & 0.3 & 65 \\
\hline & & $\begin{array}{c}\text { KWS } \\
\text { Kilburn } \\
\end{array}$ & 251 & 17.1 & 74 & 41 & 0.3 & 58 \\
\hline \multirow{14}{*}{+} & & mean & 234 & 16.9 & 73 & 42 & 0.3 & 59 \\
\hline & & Paragon & 223 & 27.4 & 102 & 65 & 0.5 & 56 \\
\hline & & Mulika & 284 & 20.1 & 127 & 65 & 0.4 & 57 \\
\hline & & Zircon & 338 & 22.8 & 154 & 62 & 0.5 & 74 \\
\hline & - & Granary & 257 & 20.8 & 111 & 61 & 0.4 & 68 \\
\hline & & $\begin{array}{l}\text { KWS } \\
\text { Willow }\end{array}$ & 302 & 22.4 & 97 & 61 & 0.3 & 70 \\
\hline & & $\begin{array}{l}\text { KWS } \\
\text { Kilburn }\end{array}$ & 269 & 21.3 & 97 & 55 & 0.4 & 61 \\
\hline & & mean & 279 & 22.5 & 115 & 62 & 0.4 & 64 \\
\hline & \multirow{6}{*}{+} & Paragon & 280 & 21.7 & 89 & 60 & 0.3 & 61 \\
\hline & & Mulika & 273 & 23.01 & 108 & 65 & 0.4 & 58 \\
\hline & & Zircon & 269 & 24.6 & 115 & 60 & 0.4 & 69 \\
\hline & & Granary & 269 & 22.7 & 105 & 59 & 0.4 & 65 \\
\hline & & $\begin{array}{c}\text { KWS } \\
\text { Willow }\end{array}$ & 325 & 22.9 & 102 & 64 & 0.3 & 62 \\
\hline & & $\begin{array}{c}\text { KWS } \\
\text { Kilburn } \\
\end{array}$ & 268 & 21.1 & 103 & 66 & 0.4 & 61 \\
\hline & & mean & 281 & 22.7 & 104 & 62 & 0.4 & 63 \\
\hline & & s.e.d & 30.9 & 2.1 & 13.4 & 3.6 & 0.05 & 5.3 \\
\hline
\end{tabular}




\section{Leaf tissue nutrients analysis}

483 The concentrations of leaf total N, P, K, Ca, Mg, S, Mn, Cu, Zn and B were all higher at high

484 fertilisation (main effect $\mathrm{P}<0.001$ ). However, the concentration of Fe was higher at low

485 fertilisation (main effect $\mathrm{P}=0.002$ ). The concentration of $\mathrm{B}$ in the leaves was lower in the

486 presence of $P$. indica (main effect $\mathrm{P}=0.01$ ). The combination of $P$. indica and $F$. mosseae, at

487 high fertilisation, increased the total concentration of $\mathrm{N}$ in the leaves (P. indica, F. mosseae

488 and fertiliser interaction $\mathrm{P}=0.04$ ), but on their own, each decreased the level (table 4 \&

489 supporting information 7).

490 Table 4. Leaf tissue nutrient analysis results of winter wheat samples (cv. Battalion) with 491 Piriformospora indica and Funneliformis mosseae at sowing time (fertiliser: Table 4.3. Leaf 492 nutrient analysis results of winter wheat samples inoculated with Piriformospora indica and 493 Funneliformis mosseae at sowing time (fertiliser: Osmocote ${ }^{\circledR}$ Pro slow release fertiliser, N:

494 Nitrogen, P: phosphorus, K: potassium, Ca: calcium, Mg: magnesium, S: sulphur, Mn: 495 manganese, $\mathrm{Cu}$ : copper, Zn: zinc, Fe: Iron, B: boron ; d.f. = 14).

\begin{tabular}{|c|c|c|c|c|c|c|c|c|c|c|c|c|c|}
\hline Fertiliser & P.indica & F.mosseae & $\begin{array}{c}\text { Total } \\
\mathrm{N} \\
\end{array}$ & $\begin{array}{c}\text { Total } \\
\mathrm{P}\end{array}$ & $\begin{array}{c}\text { Total } \\
\mathrm{K} \\
\end{array}$ & $\begin{array}{l}\text { Ttal } \\
\mathrm{Ca} \\
\end{array}$ & $\begin{array}{c}\text { Total } \\
\mathrm{Mg}\end{array}$ & Total S & $\begin{array}{c}\text { Total } \\
\mathrm{Mn}\end{array}$ & Total $\mathrm{Cu}$ & $\begin{array}{c}\text { Total } \\
\mathrm{Zn}\end{array}$ & $\begin{array}{c}\text { Total } \\
\mathrm{Fe} \\
\end{array}$ & $\begin{array}{c}\text { Total } \\
\text { B }\end{array}$ \\
\hline \multirow{6}{*}{$1 \mathrm{~g} / \mathrm{L}$} & \multirow{3}{*}{-} & - & 3 & 4471 & 35830 & 2849 & 908 & 2649 & 123 & 4 & 29 & 517 & 3 \\
\hline & & + & 3 & 5163 & 40524 & 2803 & 1020 & 3564 & 139 & 4 & 32 & 192 & 3 \\
\hline & & Mean & 3 & 4817 & 38177 & 2826 & 964 & 3107 & 131 & 4 & 31 & 355 & 3 \\
\hline & \multirow{2}{*}{+} & - & 3 & 4989 & 39836 & 2771 & 1029 & 3443 & 152 & 5 & 31 & 214 & 3 \\
\hline & & + & 3 & 4906 & 38003 & 2689 & 1003 & 3125 & 142 & 4 & 31 & 173 & 3 \\
\hline & & Mean & 3 & 4948 & 38920 & 2730 & 1016 & 3284 & 147 & 5 & 31 & 194 & 3 \\
\hline \multirow{5}{*}{$4 \mathrm{~g} / \mathrm{L}$} & \multirow[b]{2}{*}{ - } & - & 5 & 7803 & 52583 & 4120 & 1540 & 7440 & 216 & 8 & 60 & 157 & 4 \\
\hline & & + & 4 & 7465 & 51042 & 3638 & 1382 & 6479 & 209 & 6 & 53 & 121 & 4 \\
\hline & & Mean & 5 & 7634 & 51813 & 3879 & 1461 & 6960 & 213 & 7 & 57 & 139 & 4 \\
\hline & \multirow{2}{*}{+} & - & 4 & 7995 & 52829 & 3668 & 1406 & 6790 & 204 & 7 & 56 & 135 & 3 \\
\hline & & + & 5 & 7106 & 52588 & 4065 & 1553 & 6018 & 177 & 6 & 54 & 121 & 3 \\
\hline & & Mean & 5 & 7551 & 52709 & 3867 & 1480 & 6404 & 191 & 7 & 55 & 128 & 3 \\
\hline & & s.e.d & 0.3 & 632 & 3500 & 450 & 132 & 715 & 15 & 0.6 & 5 & 76 & 0.3 \\
\hline
\end{tabular}

496

497

498

499 


\section{Discussion}

$P$. indica effectively reduced FHB disease severity and incidence, and also grain DON contamination. It was as effective as fungicide applied 72 hours after $F$. graminearum inoculation, and the effect was consistent across years and cultivars. $P$. indica also increased yield in both high and low fertilisation, suggesting $P$. indica application is compatible with low-input systems. However, unlike mycorrhizal fungi, its effect was greater at the high fertilisation level. $P$. indica application was compatible with $F$. mosseae and fungicide, but effects of these were not additive. Collectively, these results suggest that $P$. indica application could be useful in the long-term. $P$. indica reduced FCR at sowing, FHB at flowering and grain DON contamination, suggesting there would be fewer spores, hyphae and macroconidia overwintering in soil and crop residues; as a result there would be less inoculum available for the disease to occur in the next season.

513 Fungicide application during wheat growing stages can reduce the risk of FHB and mycotoxin contamination (Edwards \& Godley, 2010, Paul et al., 2008). However, inconsistent control of FHB disease with fungicide has been found in several reports (Horsley et al., 2006, McMullen, 1994). Yoshida et al. (2012) indicated that the timing of fungicide application differentially affected FHB disease and mycotoxin concentration, considering anthesis as the crucial stage for fungicide application. The application of fungicide, in our spring wheat experiment, at GS 39 (when flag leaf was fully emerged), and then at anthesis GS 65 (72 hours after Fusarium inoculation), reduced both FHB and DON concentration. In all spring and winter wheat experiments, $P$. indica application at sowing also reduced FHB severity and incidence as effectively as fungicide. The application of $P$. indica not only might reduce the use of fungicide and any environmental damage from fungicide use, but also increase plant resistance against other pathogens (Franken, 2012). 
525 The DON concentration in samples inoculated at sowing with $F$. culmorum and then at heading with $F$. graminearum was much higher than in samples inoculated only with $F$. graminearum. This suggests that when Fusarium is already present in the plant, there is an increased risk of mycotoxin production in the grains by FHB. F. culmorum might have produced DON that moved from lower parts of the plants to the heads, consistent with the results of Moretti et al.

530 (2014) and Covarelli et al. (2012) who demonstrated that although $F$. graminearum and $F$. culmorum could not be detected beyond the third internode, a low concentration of DON was found in the kernels beyond those tissues colonized by the fungus; suggesting that DON can be moved from lower parts of the plants to the heads. This is probably due to its water solubility, which can cause a reduction in concentration at late harvest, but in this case led to transfer upwards. Alternatively, Mudge et al. (2006) isolated F. graminearum and DON from wheat heads and flag leaf nodes following inoculation of the stem base. Xu et al. (2007) indicated that the mycotoxin productivity of $F$. graminearum in the co-inoculation with $F$. culmorum and $F$. poae was higher of that in the single-isolate inoculations. However, in the present case DON levels in the ear were not detectably increased by root infection with $F$. culmorum in the

540 absence of $F$. graminearum inoculation. The increased production of DON is therefore presumably connected to increased plant resistance.

In the winter wheat experiment, $P$. indica increased the above ground weight, total grain weight and 1000 grain weight by similar amounts under both low and high fertilisation, suggesting that the $P$. indica effect on grain yield was independent of fertiliser levels. Similarly Achatz et al. (2010) found that increased grain yield in P. indica inoculated barley was independent of the fertilisation level. Murphy et al. (2014) found that $P$. indica-inoculated barley had greater grain weight in higher nutrient input. These indicates that $P$. indica-induced yield increase does not result from relief of low phosphorus or nitrogen supply. By contrast, both our results 
549 and those of Achatz et al. suggest that the increase in the above ground weight caused by $F$.

550 mosseae only occurred under low fertility. The difference in response to high fertility shows

551 that the beneficial effects of $P$. indica are based on different mechanisms from mycorrhizal

552 fungi. The effect of $P$. indica under low and high fertilisation levels on final yield of winter

553 wheat was confirmed on a small scale experiment (data not shown, see supportive information

$5548 \& 9)$.

555 Consistently with our results, Shahabivand et al. (2012) and Yaghoubian et al. (2014) reported

556 that $P$. indica increased wheat growth more than $F$. mosseae and that their co-inoculation

557 improved the defence mechanisms, drought resistance, and growth of wheat plants, suggesting

$558 \quad P$. indica application was compatible with $F$. mosseae application.

559 During the experiments we scored the severity of any air borne diseases which occurred naturally. $P$. indica reduced disease severity and incidence of Septoria leaf blotch at GS 22

561 (tillering stage) and yellow rust at GS 35-37 (stem elongation, 5th node detectable to flag leaf just visible) for the winter wheat cv. Battalion, and yellow rust and powdery mildew at GS 70 (milk development) for six different cultivars of spring wheat (data not shown). In a smallscale experiment the effect of $P$. indica on Septoria leaf blotch was confirmed at seedling stage; this is consistent with $P$. indica producing a generalised increase in resistance to a wide class of fungi.

These results show that $P$. indica colonised and increased shoot and final yield of the winter wheat (cv. Battalion) and 6 cultivars of spring wheat. $P$. indica reduced disease severity and incidence of FHB, and other foliar diseases and DON concentration of all cultivars. It is consistent with Deshmukh et al. (2006), Deshmukh and Kogel (2007)'s study. They inoculated different barley cultivar seedlings with $P$. indica and different isolates of Sebacina vermifera (member of Sebacinaceae, genetically close to $P$. indica). Despite considerable variation of the 
573 fungal activity of the different isolates, they found an increase in shoot and root biomass with consistent resistance-inducing activity of all strains of the $S$. vermifera against powdery mildew (caused by Blumeria graminis f.sp. hordei) as with P. indica. In contrast, Gravouil (2012) showed that different barley cultivars had different rates of colonisation by $P$. indica. Some barley cultivars had the highest rate of $P$. indica colonisation and the best increase in shoot biomass and protection against pathogens such as Rhynchosporium commune.

The leaf tissue nutrient analysis showed that $P$. indica did not have any effect on leaf nutrients, suggesting that at least in the case of this experiment, $P$. indica effects on growth and yield were not due to better nutrient uptake. These results are inconsistent with others that suggest $P$. indica increasing the uptake of micro- and macro-nutrients leads to growth promotion (Shrivastava \& Varma, 2014). Gosal et al. (2010) reported that $P$. indica increased the amount of $\mathrm{Cu}, \mathrm{Zn}$ and $\mathrm{Mn}$ in Chlorophytum sp. and promoted plant growth and biomass. P. indica increased the amount of $\mathrm{Zn}$ in Turmeric (Curcuma longa L.) which enhanced the growth, yield and active ingredients (Bajaj et al., 2014). The inconsistency with their results might have various causes. It might be due to the host differences, the methods of plant cultivations and inoculations, environmental effects or differences in the fertilisers and their concentrations. However, F. mosseae also did not have any effects on leaf nutrients, suggesting no effect of $P$. indica and/or $F$. mosseae might be because of the experimental conditions. So more experiments are needed to confirm that.

These results suggest that $P$. indica could be useful in control of Fusarium crown rot and head blight, mycotoxin contamination and other air borne diseases. However, $P$. indica is probably an alien species in many parts of the world including the UK, so its releases into the open environments in these regions, to confirm its beneficial effects, requires consideration also of physiological trade-offs and ecological and agronomical side-effects. The wider effects of $P$. 
indica and similar organisms also need to be better understood before agricultural deployment.

A search for native organisms with similar characteristics might be a safer direction to go in.

Acknowledgment

This work was funded by the Sir Halley Stewart Trust.

601

602

603

604

605

606

607

608

609

610

611

612

613

614

615

616

617

618

619

620

621

622

623

624

625

626

627

628

629

630

\section{References}

Achatz B, Von Ruden S, Andrade D, Neumann E, Pons-Kuhnemann J, Kogel KH, Franken P, Waller F, 2010. Root colonization by Piriformospora indica enhances grain yield in barley under diverse nutrient regimes by accelerating plant development. Plant and Soil 333, 59-70.

Alikhani M, Khatabi B, Sepehri M, Nekouei MK, Mardi M, Salekdeh GH, 2013. A proteomics approach to study the molecular basis of enhanced salt tolerance in barley (Hordeum vulgare L.) conferred by the root mutualistic fungus Piriformospora indica. Molecular Biosystems $\mathbf{9}$, 1498-510. http://www.rsc.org/molecularbiosystems.

Anon, 2006. Commission Regulation (EC) No 1881/2006 setting maximum levels of certain contaminants in foodstuffs. Official Journal of the European Union L364:5-24.

Bai G-H, Shaner GE, 2004. Management and resistance in wheat and barley to Fusarium head blight. Annual Review Phytopathology 42, 135-61.

Bajaj R, Agarwal A, Rajpal K, Asthana S, Prasad R, Kharkwal AC, Kumar R, Sherameti I, Oelmüller R, Varma. A, 2014. Co-cultivation of Curcuma longa with Piriformospora indica Enhances the Yield and Active Ingredients. American Journal of Current Microbiology 2, 112.

Bucher M, 2007. Functional biology of plant phosphate uptake at root and mycorrhiza interfaces. New Phytologist 173, 11-26.

Covarelli L, Beccari G, Steed A, Nicholson P, 2012. Colonization of soft wheat following infection of the stem base by Fusarium culmorum and translocation of deoxynivalenol to the head. Plant Pathology 61, 1121-9.

Deshmukh S, Hueckelhoven R, Schaefer P, Imani J, Sharma M, Weiss M, Waller F, Kogel KH, 2006. The root endophytic fungus Piriformospora indica requires host cell death for proliferation during mutualistic symbiosis with barley. Proceedings of the National Academy of Sciences of the United States of America 103, 18450-7.

Deshmukh SD, Kogel KH, 2007. Piriformospora indica protects barley from root rot caused by Fusarium graminearum. Journal of Plant Diseases and Protection 114, 263-8.

Edwards SG, Godley NP, 2010. Reduction of Fusarium head blight and deoxynivalenol in wheat with early fungicide applications of prothioconazole. Food Additives and Contaminants Part a-Chemistry Analysis Control Exposure \& Risk Assessment 27, 629-35. 
631 Fernandez MR, Chen Y, 2005. Pathogenicity of Fusarium species on different plant parts of 632 spring wheat under controlled conditions. Plant Disease 89, 164-9.

633 Finlay RD, 2008. Ecological aspects of mycorrhizal symbiosis: with special emphasis on the 634 functional diversity of interactions involving the extraradical mycelium. $J$ Exp Bot 59, 111563526.

636 Franken P, 2012. The plant strengthening root endophyte Piriformospora indica: potential 637 application and the biology behind. Applied Microbiology and Biotechnology 96, 1455-64. 638 http://link.springer.com/.

639 Ghabooli M, Khatabi B, Ahmadi FS, Sepehri M, Mirzaei M, Amirkhani A, Jorrin-Novo JV, 640 Salekdeh GH, 2013. Proteomics study reveals the molecular mechanisms underlying water 641 stress tolerance induced by Piriformospora indica in barley. J Proteomics 94, 289-301.

642 Ghahfarokhy MR, Goltapeh EM, Purjam E, Pakdaman, B.S., Modarres Sanavy SaM, Varma 643 A, 2011. Potential of mycorrhiza-like fungi and Trichoderma species in biocontrol of Take-all 644 Disease of wheat under greenhouse condition Journal of Agricultural Technology 7(1), 185645 95. http://www.ijat-aatsea.com/.

646 Gosal SK, Karlupia A, Gosal SS, Chhibba IM, Varma A, 2010. Biotization with Piriformospora 647 indica and Pseudomonas fluorescens improves survival rate, nutrient acquisition, field 648 performance and saponin content of micropropagated Chlorophytum sp. . Indian Journal of 649 Biotechnology 9, 289-97.

650 Gravouil C, 2012. Identification of the barley phyllosphere and the characterisation of 651 manipulation means of the bacteriome against leaf scald and powdery mildew. PhD thesis: 652 University of Nottingham.

653 Harrach BD, Baltruschat H, Barna B, Fodor J, Kogel K-H, 2013. The Mutualistic Fungus 654 Piriformospora indica Protects Barley Roots from a Loss of Antioxidant Capacity Caused by 655 the Necrotrophic Pathogen Fusarium culmorum. Molecular Plant-Microbe Interactions 26, 656 599-605.

657 Horsley RD, Pederson JD, Schwarz PB, Mckay K, Hochhalter MR, Mcmullen MP, 2006. 658 Integrated use of tebuconazole and fusarium head blight-resistant barley genotypes. Agronomy 659 Journal 98, 194-7.

660 Leplat J, Friberg H, Abid M, Steinberg C, 2013. Survival of Fusarium graminearum, the causal 661 agent of Fusarium head blight. A review. Agronomy for Sustainable Development 33, 97-111.

662 Madgwick JW, West JS, White RP, Semenov MA, Townsend JA, Turner JA, Fitt BDL, 2011. 663 Impacts of climate change on wheat anthesis and fusarium ear blight in the UK. European 664 Journal of Plant Pathology 130, 117-31.

665 Mcmullen MP, 1994. Foliar fungicide control of Septoria leaf blight and Fusarium head scab 666 of wheat. Fungicide and Nematicide Tests 49, 226. 
667 Mesterházy Á, 2003. Control of Fusarium head blight of wheat by fungicides. In: K. J. Leonard 668 and W. R. Bushnell E, ed. Fusarium Head Blight of Wheat and Barley. The American 669 Phytopathological Society, St. Paul, MN, pp 363-380.

670 Miransari M, 2010. Contribution of arbuscular mycorrhizal symbiosis to plant growth under different types of soil stress. Plant Biol (Stuttg) 12, 563-9.

Moretti A, Panzarini G, Somma S, Campagna C, Ravaglia S, Logrieco AF, Solfrizzo M, 2014. Systemic Growth of F. graminearum in Wheat Plants and Related Accumulation of Deoxynivalenol. Toxins 6, 1308-24.

Mudge AM, Dill-Macky R, Dong YH, Gardiner DM, White RG, Manners JM, 2006. A role for the mycotoxin deoxynivalenol in stem colonisation during crown rot disease of wheat caused by Fusarium graminearum and Fusarium pseudograminearum. Physiological and Molecular Plant Pathology 69, 73-85.

Murphy B, R.,, Doohan F, M.,, Hodkinson T, R., 2014. Yield increase induced by the fungal root endophyte Piriformospora indica in barley grown at low temperature is nutrient limited. Symbiosis 62, 29-39.

Nouri E, Breuillin-Sessoms F, Feller U, Reinhardt D, 2015. Phosphorus and Nitrogen Regulate Arbuscular Mycorrhizal Symbiosis in Petunia hybrida. Plos One 10, doi: 10.1371/journal.pone.0127472.

Paul PA, Lipps PE, Hershman DE, Mcmullen MP, Draper MA, Madden LV, 2008. Efficacy of triazole-based fungicides for Fusarium head blight and deoxynivalenol control in wheat: A multivariate meta-analysis. Phytopathology 98, 999-1011.

Paulitz TC, Smiley RW, Cook RJ, 2002. Insights into the prevalence and management of soilborne cereal pathogens under direct seeding in the Pacific Northwest, U.S.A. Canadian Jouranl of Plant Pathology 24, 416-28.

Rabiey M, Ullah I, Shaw MW, 2015. The endophytic fungus Piriformospora indica protects wheat from fusarium crown rot disease in simulated UK autumn conditions. Plant Pathology 64, 1029-40. DOI: 10.111/ppa.12335.

Schalamuk S, Cabello MN, Chidichimo H, Golik S, 2011. Effects of Inoculation with Glomus mosseae in Conventionally Tilled and Nontilled Soils with Different Levels of Nitrogen Fertilization on Wheat Growth, Arbuscular Mycorrhizal Colonization, and Nitrogen Nutrition. Communications in Soil Science and Plant Analysis 42, 586-98.

Shahabivand S, Maivan HZ, Goltapeh EM, Sharifi M, Aliloo AA, 2012. The effects of root endophyte and arbuscular mycorrhizal fungi on growth and cadmium accumulation in wheat

Sherameti I, Shahollari B, Venus Y, Altschmied L, Varma A, Oelmuller R, 2005. The endophytic fungus Piriformospora indica stimulates the expression of nitrate reductase and the starch-degrading enzyme glucan-water dikinase in tobacco and Arabidopsis roots through a homeodomain transcription factor that binds to a conserved motif in their promoters. Journal of Biological Chemistry 280, 26241-7. 
Shrivastava S, Varma A, 2014. From Piriformospora indica to rootonic: a review. African Journal of Microbiology Research 8, 2984-92.

Verma S, Varma A, Rexer KH, Hassel A, Kost G, Sarbhoy A, Bisen P, Butehorn B, Franken P, 1998. Piriformospora indica, gen. et sp. nov., a new root-colonizing fungus. Mycologia $\mathbf{9 0}$, 896-903.

Waller F, Achatz B, Baltruschat H, Fodor J, Becker K, Fischer M, Heier T, Huckelhoven R, Neumann C, Von Wettstein D, Franken P, Kogel KH, 2005. The endophytic fungus Piriformospora indica reprograms barley to salt-stress tolerance, disease resistance, and higher yield. Proceedings of the National Academy of Sciences of the United States of America 102, 13386-91.

West JS, Holdgate S, Townsend JA, Edwards SG, Jennings P, Fitt BDL, 2012. Impacts of changing climate and agronomic factors on fusarium ear blight of wheat in the UK. Fungal Ecology 5, 53-61.

Wu QS, Li GH, Zou YN, 2011. Roles of arbuscular mycorrhizal fungi on growth and nutrient acquisition of peach (Prunus persica L. Batsch) seedlings. Journal of Animal and Plant Science 21, 746-50.

Xu XM, Monger W, Ritieni A, Nicholson P, 2007. Effect of temperature and duration of wetness during initial infection periods on disease development, fungal biomass and mycotoxin concentrations on wheat inoculated with single, or combinations of, Fusarium species. Plant Pathology 56, 943-56.

Xu XM, Parry DW, Nicholson P, Thomsett MA, Simpson D, Edwards SG, Cooke BM, Doohan FM, Monaghan S, Moretti A, Tocco G, Mule G, Hornok L, Beki E, Tatnell J, Ritieni A, 2008. Within-field variability of Fusarium head blight pathogens and their associated mycotoxins. European Journal of Plant Pathology 120, 21-34.

Yadav V, Kumar M, Deep DK, Kumar H, Sharma R, Tripathi T, Tuteja N, Saxena AK, Johri AK, 2010. A Phosphate Transporter from the Root Endophytic Fungus Piriformospora indica Plays a Role in Phosphate Transport to the Host Plant. Journal of Biological Chemistry 285, 26532-44.

Yaghoubian Y, Mohammadi E. G, Pirdashti H, Esfandiari E, Feiziasl V, Dolatabadi HK, Varma A, Hassim MH, 2014. Effect of Glomus mosseae and Piriformospora indica on Growth and Antioxidant Defense Responses of Wheat Plants Under Drought Stress. Agricultural Research 3, 1-7.

Yoshida M, Nakajima T, Tomimura K, Suzuki F, Arai M, Miyasaka A, 2012. Effect of the Timing of Fungicide Application on Fusarium Head Blight and Mycotoxin Contamination in Wheat. Plant Disease 96, 845-51.

Zadoks JC, Chang TT, Konzak CF, 1974. A decimal code for the growth stages of cereals. Weed Research 14, 415-21. 
755

756

757

758

759

760

761

762

763

764

765

766

767 Supporting information

768 Table 1. ANOVA P-value for variable measured in pots of winter wheat (cv. Battalion) and 769 treated in a full factorial design with the factors shown. The experiment carried out in the 770 2013/14 growing season. 
Page 36 of 40

\begin{tabular}{|c|c|c|c|c|c|c|c|c|}
\hline & $\begin{array}{c}\text { FHB } \\
\text { severity }\end{array}$ & $\begin{array}{c}\text { FHB } \\
\text { incidence }\end{array}$ & $\begin{array}{c}\text { Total above ground } \\
\text { weight }\end{array}$ & $\begin{array}{l}\text { Root } \\
\text { weight }\end{array}$ & $\begin{array}{l}\text { Total grain } \\
\text { weight }\end{array}$ & TGW & $\begin{array}{l}\text { Harvest } \\
\text { index }\end{array}$ & $\begin{array}{c}\text { No of } \\
\text { ears }\end{array}$ \\
\hline \multicolumn{9}{|l|}{ Main effect } \\
\hline P.indica & $<.001$ & $<.001$ & 0.06 & $<.001$ & 0.2 & 0.02 & 0.6 & 0.2 \\
\hline F.mosseae & 0.001 & 0.006 & 0.01 & $<.001$ & 0.3 & 0.05 & 0.9 & 0.02 \\
\hline Fertiliser & $<.001$ & $<.001$ & $<.001$ & $<.001$ & $<.001$ & 0.6 & 0.3 & $<.001$ \\
\hline F.graminearum & $<.001$ & $<.001$ & 0.2 & 0.9 & 0.09 & 0.06 & 0.2 & 0.8 \\
\hline F.culmorum & 0.09 & 0.1 & 0.09 & 0.05 & 0.2 & 0.8 & 0.6 & 0.9 \\
\hline \multicolumn{9}{|l|}{ 2nd order interaction } \\
\hline P.indica.F.mosseae & 0.008 & 0.03 & 0.06 & $<.001$ & 0.7 & 0.2 & 0.6 & 0.3 \\
\hline P.indica.Fertiliser & 0.7 & 0.2 & 0.9 & 0.3 & 0.8 & 0.5 & 0.9 & 0.7 \\
\hline F.mosseae.Fertiliser & 0.6 & 0.9 & 0.004 & 0.4 & 0.03 & 0.8 & 0.2 & 0.7 \\
\hline P.indica.F.g & 0.004 & 0.005 & 0.4 & 0.03 & 0.9 & 0.04 & 0.8 & 0.1 \\
\hline F.mosseae.F.g & 0.1 & 0.3 & 0.4 & 0.2 & 0.6 & 0.7 & 0.4 & 0.7 \\
\hline Fertiliser.F.g & 0.7 & 0.5 & 0.9 & 0.8 & 0.6 & 0.5 & 0.7 & 0.3 \\
\hline P.indica.F.c & 0.2 & 0.1 & 0.6 & 0.01 & 0.9 & 0.8 & 0.5 & 0.7 \\
\hline F.mosseae.F.c & 0.03 & 0.01 & $<.001$ & 0.01 & 0.07 & 0.6 & 0.7 & 0.5 \\
\hline Fertiliser.F.c & 0.7 & 0.9 & 0.8 & $<.001$ & 0.7 & 0.7 & 0.6 & 0.3 \\
\hline F.graminearum.F.c & 0.4 & 0.5 & 0.9 & 0.6 & 0.9 & 0.02 & 0.8 & 0.9 \\
\hline \multicolumn{9}{|l|}{ 3rd order interaction } \\
\hline P.indica.F.mosseae.Fertiliser & 0.6 & 0.7 & 0.9 & 0.05 & 0.5 & 0.008 & 0.4 & 0.02 \\
\hline P.indica.F.mosseae.F.g & 0.08 & 0.05 & 0.008 & 0.7 & 0.09 & 0.7 & 0.5 & 0.9 \\
\hline P.indica.Fertiliser.F.g & 0.9 & 0.5 & 0.9 & 0.04 & 0.2 & 0.8 & 0.1 & 0.6 \\
\hline F.mosseae.Fertiliser.F.g & 0.6 & 0.9 & 0.001 & 0.1 & 0.4 & 0.09 & 0.5 & 0.7 \\
\hline P.indica.F.mosseae.F.c & 0.4 & 0.7 & 0.07 & 0.008 & 0.05 & 0.4 & 0.2 & 0.3 \\
\hline P.indica.Fertiliser.F.c & 0.6 & 0.7 & 0.3 & 0.2 & 0.4 & 0.3 & 0.5 & 0.8 \\
\hline F.mosseae.Fertiliser.F.c & 0.6 & 0.4 & 0.06 & 0.4 & 0.3 & 0.7 & 0.9 & 0.4 \\
\hline P.indica.F.g.F.c & 0.8 & 0.2 & 0.6 & 0.3 & 0.7 & 0.9 & 0.9 & 0.3 \\
\hline F.mosseae.F.g.F.c & 0.6 & 0.3 & 0.4 & 0.9 & 0.1 & 0.04 & 0.2 & 0.7 \\
\hline Fertiliser.F.g.F.c & 0.07 & 0.04 & 0.1 & 0.5 & 0.9 & 0.8 & 0.4 & 0.5 \\
\hline \multicolumn{9}{|l|}{ 4th order interaction } \\
\hline P.indica.F.mosseae.Fertiliser.F.g & 0.5 & 0.7 & 0.1 & 0.2 & 0.2 & 0.7 & 0.6 & 0.9 \\
\hline P.indica.F.mosseae.Fertiliser.F.c & 0.2 & 0.03 & 0.9 & 0.008 & 0.4 & 0.7 & 0.6 & 0.8 \\
\hline P.indica.F.mosseae.F.g.F.c & 0.05 & 0.01 & 0.8 & 0.8 & 0.8 & 0.4 & 0.7 & 0.09 \\
\hline P.indica.Fertiliser.F.g.F.c & 0.06 & 0.04 & 0.4 & 0.4 & 0.7 & 0.1 & 0.8 & 0.9 \\
\hline F.mosseae.Fertiliser.F.g.F.c & 0.4 & 0.3 & 0.4 & 0.5 & 0.6 & 0.3 & 0.9 & 0.6 \\
\hline \multicolumn{9}{|l|}{ 5th order interaction } \\
\hline P.indica.F.mosseae.Fertiliser.F.g.F.c & 0.7 & 0.9 & 0.4 & 0.8 & 0.6 & 0.8 & 0.8 & 0.5 \\
\hline
\end{tabular}

771

772 Table 2. ANOVA P-value for variable measured in pots of spring wheat (cv. Paragon) and 773 treated in a full factorial design with the factors shown. The experiment carried out in the 2014 774 growing season. 
Page $\mathbf{3 7}$ of $\mathbf{4 0}$

\begin{tabular}{|c|c|c|c|c|c|c|c|c|}
\hline \multirow[b]{2}{*}{ Main effect } & \multicolumn{8}{|c|}{$P$ value } \\
\hline & $\begin{array}{l}\text { FHB } \\
\text { severity }\end{array}$ & $\begin{array}{c}\text { FHB } \\
\text { incidence }\end{array}$ & $\begin{array}{l}\text { Total above } \\
\text { ground weight }\end{array}$ & $\begin{array}{l}\text { Root } \\
\text { weight }\end{array}$ & $\begin{array}{l}\text { Total grain } \\
\text { weight }\end{array}$ & $\begin{array}{l}1000 \text { grain } \\
\text { weight }\end{array}$ & $\begin{array}{l}\text { Harvest } \\
\text { index }\end{array}$ & $\begin{array}{l}\text { No of } \\
\text { ears }\end{array}$ \\
\hline P.indica & 0.07 & 0.2 & 0.05 & 0.02 & 0.02 & 0.08 & 0.07 & 0.003 \\
\hline F.mosseae & 0.8 & 0.6 & 0.1 & 0.2 & 0.1 & 0.5 & 0.5 & 0.1 \\
\hline F.graminearum & $<.001$ & $<.001$ & 0.8 & 0.8 & 0.8 & 0.4 & 0.7 & 0.03 \\
\hline Fungicide & 0.005 & 0.02 & 0.6 & 0.7 & 0.05 & 0.7 & 0.03 & 0.12 \\
\hline \multicolumn{9}{|l|}{ 2nd order interaction } \\
\hline P.indica.F.mosseae & 0.4 & 0.5 & 0.8 & 0.03 & 0.7 & 0.1 & 0.3 & 0.4 \\
\hline P.indica.F.g & 0.2 & 0.4 & 0.4 & 0.6 & 0.08 & 0.1 & 0.07 & 0.9 \\
\hline F.mosseae.F.g & 0.7 & 0.6 & 0.09 & 0.05 & 0.2 & 0.1 & 0.7 & 0.06 \\
\hline P.indica. Fungicide & 0.08 & 0.3 & 0.3 & 0.2 & 0.8 & 0.1 & 0.4 & 0.6 \\
\hline F.mosseae. Fungicide & 0.4 & 0.3 & 0.8 & 0.3 & 0.3 & 0.2 & 0.1 & 0.8 \\
\hline Fusarium. Fungicide & 0.04 & 0.1 & 0.5 & 0.4 & 0.9 & 0.8 & 0.4 & 0.9 \\
\hline \multicolumn{9}{|l|}{ 3rd order interaction } \\
\hline P.indica.F.mosseae.F.g & 0.8 & 0.9 & 0.7 & 0.01 & 0.6 & 0.6 & 0.7 & 0.7 \\
\hline $\begin{array}{l}\text { P.indica.F.mosseae. } \\
\text { Fungicide }\end{array}$ & 0.9 & 0.9 & 0.03 & 0.9 & 0.003 & 0.01 & 0.009 & 0.003 \\
\hline P.indica.F.g. Fungicide & 0.1 & 0.3 & 0.7 & 0.8 & 0.4 & 0.9 & 0.3 & 0.7 \\
\hline F.mosseae.F.g.Fungicide & 0.5 & 0.6 & 0.8 & 0.6 & 0.4 & 0.8 & 0.1 & 0.4 \\
\hline \multicolumn{9}{|l|}{ 4th order interaction } \\
\hline $\begin{array}{l}\text { P.indica.F.mosseae.F.g. } \\
\text { Fungicide }\end{array}$ & 0.7 & 0.6 & 0.2 & 0.3 & 0.3 & 0.5 & 0.9 & 0.5 \\
\hline
\end{tabular}

784 Table 3. ANOVA P-value for variable measured in pots of six cultivars of spring wheat (cv. 785 Paragon, Mulika, Zircon, Granary, KWS Willow and KWS Kilburn) and treated in a full 786 factorial design with the factors shown. The experiment carried out in the 2015 growing season. 
Page 38 of 40

\begin{tabular}{|c|c|c|c|c|c|c|c|c|}
\hline \multirow[b]{2}{*}{ Main effect } & \multicolumn{8}{|c|}{$\mathrm{P}$ value } \\
\hline & $\begin{array}{c}\text { FHB } \\
\text { severity }\end{array}$ & $\begin{array}{c}\text { FHB } \\
\text { incidence }\end{array}$ & $\begin{array}{l}\text { Total above } \\
\text { ground weight }(\mathrm{g})\end{array}$ & $\begin{array}{c}\text { Root } \\
\text { weight } \\
(\mathrm{g}) \\
\end{array}$ & $\begin{array}{c}\text { Total grain } \\
\text { weight per pot }(\mathrm{g})\end{array}$ & $\begin{array}{l}1000 \text { grain } \\
\text { weight }(\mathrm{g})\end{array}$ & $\begin{array}{l}\text { Harvest } \\
\text { index }\end{array}$ & $\begin{array}{c}\text { No of } \\
\text { ears }\end{array}$ \\
\hline P.indica & $<.001$ & $<.001$ & 0.002 & $<.001$ & $<.001$ & $<.001$ & $<.001$ & 0.002 \\
\hline F.graminearum & $<.001$ & $<.001$ & 0.06 & 0.6 & $<.001$ & 0.2 & 0.034 & 0.6 \\
\hline Wheat cultivars & $<.001$ & $<.001$ & 0.02 & 0.09 & 0.001 & 0.1 & 0.1 & $<.001$ \\
\hline \multicolumn{9}{|c|}{ 2nd order interaction } \\
\hline P.indica.F.g & $<.001$ & 0.02 & 0.04 & 0.8 & 0.2 & 0.03 & 0.6 & 0.6 \\
\hline $\begin{array}{l}\text { P.indica.wheat } \\
\text { cultivars }\end{array}$ & 0.7 & 0.8 & 0.9 & 0.9 & 0.3 & 0.4 & 0.6 & 0.8 \\
\hline $\begin{array}{l}\text { FHB.wheat } \\
\text { cultivars }\end{array}$ & 0.9 & 0.9 & 0.5 & 0.1 & 0.7 & 0.8 & 0.9 & 0.7 \\
\hline \multicolumn{9}{|c|}{ 3rd order interaction } \\
\hline $\begin{array}{l}\text { P.indica.F.g.wheat } \\
\text { cultivars }\end{array}$ & 0.2 & 0.2 & 0.3 & 0.5 & 0.3 & 0.5 & 0.2 & 0.6 \\
\hline
\end{tabular}

787

788 Table 4. for Fig 4a. ANOVA table of mycotoxin DON of winter wheat (cv. Battalion).

\begin{tabular}{lc}
\cline { 2 - 2 } & \multicolumn{1}{c}{ P value } \\
\cline { 2 - 2 } main effect & $\begin{array}{c}\text { DON } \\
\text { DOn }\end{array}$ \\
\hline P. indica & $<.001$ \\
F. culmorum & $<.001$ \\
Fertiliser & $\mathbf{0 . 0 0 5}$ \\
F. mosseae & 0.5 \\
\hline 2rd order interaction & \\
P.indica.F. culmorum & $<.001$ \\
P_indica.Fertiliser & $\mathbf{0 . 0 0 1}$ \\
Fertiliser.F.culmorum & 0.09 \\
P.indica.F.mosseae & $\mathbf{0 . 0 0 3}$ \\
F.mosseae.F. culmorum & 0.3 \\
F.mosseae.Fertiliser & 0.4 \\
\hline 3rd order interaction & \\
P.indica.Fertiliser.F.c & $\mathbf{0 . 0 5}$ \\
P.indica.F.mosseae.F.c & 0.6 \\
P.indica.F.mosseae.Fertiliser & 0.4 \\
F.mosseae.Fertiliser.F.c & 0.2 \\
\hline 4th order interaction & \\
P.indica.F.mosseae.Fertiliser.F.c & 0.1 \\
\hline
\end{tabular}

791 Table 5. for Fig 4b. ANOVA table of mycotoxin DON of spring wheat (cv. Paragon). 


\begin{tabular}{lc}
\cline { 2 - 2 } main effect & P value \\
\cline { 2 - 2 } & $\begin{array}{c}\text { Mycotoxin } \\
\text { DON }\end{array}$ \\
\hline P.indica & $\mathbf{0 . 0 1}$ \\
F.mosseae & 0.5 \\
Fungicide & $\mathbf{0 . 0 0 1}$ \\
\hline 2nd way interaction & \\
P.indica.F.mosseae & $\mathbf{0 . 0 0 9}$ \\
P.indica.Fungicide & $\mathbf{0 . 0 3}$ \\
F.mosseae.Fungicide & 0.9 \\
\hline 3rd way interaction & \\
P.indica.F.mosseae.Fungicide & 0.06 \\
\hline
\end{tabular}

793 Table 6. for Fig 4c. ANOVA table of mycotoxin DON of six cultivars of spring wheat (cv.

794 Paragon, Mulika, Zircon, Granary, KWS Willow and KWS Kilburn).

\begin{tabular}{lc}
\cline { 2 - 2 } & \multicolumn{1}{c}{ P value } \\
\cline { 2 - 2 } Main effect & Mycotoxin DON \\
\hline P.indica & $<.001$ \\
Wheat cultivars & $<.001$ \\
\hline 2nd order interaction & \\
P.indica. Wheat cultivars & $\mathbf{0 . 0 0 2}$ \\
\hline
\end{tabular}

795

796

797

798

799

800

801

802

803

804 
805 Table 7. ANOVA P-value for variable leaf tissue nutrients measured in pots of winter wheat 806 (cv. Battalion) and treated in a full factorial design with the factors shown. The experiment 807 carried out in the 2014/15 growing season.

\begin{tabular}{|c|c|c|c|c|c|c|c|c|c|c|c|}
\hline Main effect & $\begin{array}{c}\text { Total } \\
\mathrm{N}\end{array}$ & Total P & Total K & Ttal Ca & $\begin{array}{c}\text { Total } \\
\mathrm{Mg}\end{array}$ & Total S & $\begin{array}{c}\text { Total } \\
\text { Mn }\end{array}$ & $\begin{array}{c}\text { Total } \\
\mathrm{Cu}\end{array}$ & $\begin{array}{c}\text { Total } \\
\mathrm{Zn}\end{array}$ & $\begin{array}{c}\text { Total } \\
\text { Fe }\end{array}$ & $\begin{array}{c}\text { Total } \\
\text { B }\end{array}$ \\
\hline P.indica & 0.6 & 0.9 & 0.6 & 0.8 & 0.6 & 0.6 & 0.6 & 0.7 & 0.9 & 0.04 & 0.01 \\
\hline F.mosseae & 0.7 & 0.6 & 0.9 & 0.8 & 0.7 & 0.4 & 0.4 & 0.3 & 0.5 & 0.01 & 0.2 \\
\hline Fertliser & $<.001$ & $<.001$ & $<.001$ & $<.001$ & $<.001$ & $<.001$ & $<.001$ & $<.001$ & $<.001$ & 0.002 & $<.001$ \\
\hline \multicolumn{12}{|l|}{ 2nd order interaction } \\
\hline P.indica.F.mosseae & 0.4 & 0.3 & 0.5 & 0.4 & 0.5 & 0.5 & 0.1 & 0.8 & 0.9 & 0.06 & 1 \\
\hline P.indica.Fertliser & 0.6 & 0.7 & 0.9 & 0.8 & 0.8 & 0.3 & $\mathbf{0 . 0 3}$ & 0.5 & 0.6 & 0.07 & 0.02 \\
\hline F.mosseae.Fertliser & 0.8 & 0.2 & 0.5 & 0.9 & 0.7 & 0.1 & 0.2 & 0.3 & 0.3 & 0.05 & 0.7 \\
\hline \multicolumn{12}{|l|}{ 3rd order interaction } \\
\hline P.indica.F.mosseae.Fertliser & 0.04 & 0.9 & 0.3 & 0.3 & 0.1 & 0.3 & 0.8 & 0.3 & 0.4 & 0.1 & 0.3 \\
\hline
\end{tabular}

809 Table 8. The effect of $P$. indica under low and high fertilisation levels on final yield of winter

810 wheat (cv. Battalion) was confirmed on a small scale experiment in 2014/15 growing season.

\begin{tabular}{|c|c|c|c|c|c|c|c|}
\hline Fertiliser & P.indica & $\begin{array}{l}\text { Total above } \\
\text { ground weight } \\
(\mathrm{g})\end{array}$ & $\begin{array}{l}\text { Root } \\
\text { weight } \\
(\mathrm{g})\end{array}$ & $\begin{array}{l}\text { Total grain weight } \\
\text { per pot }(\mathrm{g})\end{array}$ & $\begin{array}{l}1000 \text { grain } \\
\text { weight }(\mathrm{g})\end{array}$ & Harvest index & $\begin{array}{l}\text { No of } \\
\text { ears }\end{array}$ \\
\hline \multirow{2}{*}{$1 \mathrm{~g} / \mathrm{L}$} & - & 184 & 8.9 & 69 & 48 & 0.4 & 30 \\
\hline & + & 232 & 19.4 & 92 & 60 & 0.4 & 33 \\
\hline \multirow{3}{*}{$4 \mathrm{~g} / \mathrm{L}$} & - & 273 & 18.9 & 88 & 54 & 0.3 & 47 \\
\hline & + & 296 & 22.05 & 122 & 61 & 0.4 & 52 \\
\hline & s.e.d & 15.2 & 2.3 & 8.7 & 3.5 & 0.05 & 2.3 \\
\hline
\end{tabular}

811

812 Table 9. ANOVA P-value for variable measured in pots of winter wheat (cv. Battalion) and

813 treated in a full factorial design with the factors shown.

\begin{tabular}{lcccccc}
\cline { 2 - 7 } & \multicolumn{5}{c}{ P value } \\
\cline { 2 - 7 } Main effect & $\begin{array}{c}\text { Total above ground } \\
\text { weight }(\mathrm{g})\end{array}$ & $\begin{array}{c}\text { Root } \\
\text { weight }(\mathrm{g})\end{array}$ & $\begin{array}{c}\text { Total grain weight per } \\
\text { pot }(\mathrm{g})\end{array}$ & $\begin{array}{c}\text { 1000 grain } \\
\text { weight }(\mathrm{g})\end{array}$ & $\begin{array}{c}\text { Harvest } \\
\text { index }\end{array}$ & $\begin{array}{c}\text { No of } \\
\text { ears }\end{array}$ \\
\hline \multicolumn{1}{c}{ P.inidca } & $\mathbf{0 . 0 0 7}$ & $\mathbf{0 . 0 0 1}$ & $<.001$ & $\mathbf{0 . 0 0 3}$ & 0.2 & $\mathbf{0 . 0 5}$ \\
\multicolumn{1}{c}{ Fertliser } & $<.001$ & $\mathbf{0 . 0 0 2}$ & $\mathbf{0 . 0 0 2}$ & 0.2 & 0.6 & $<.001$ \\
\hline 2nd order & & & & 0.3 & 0.4 & 0.7 \\
interaction & 0.3 & $\mathbf{0 . 0 4}$ & 0.5 & & & \\
P.inidca.Fertliser & & & & & & \\
\hline
\end{tabular}

